\title{
EL CORPORATIVISMO EN ESPAÑA: DESDE LOS ORÍGENES A LA DÉCADA DE 1930
}

\author{
Miguel Ángel Perfecto
}

\section{INTRODUCCIÓN. DEL CORPORATIVISMO AL NEOCORPORATIVISMO}

El corporativismo, es decir, el pensamiento social que pone el acento en la estructuración de la sociedad a través de los denominados «cuerpos intermedios» supone una de las alternativas a una de las cuestiones básicas de la reflexión sociológica y política, las condiciones del "orden» o equilibrio social en una sociedad sometida a los cambios de la revolución industrial y basada en la representación política de individuos atomizados, el liberalismo político.

La sociedad liberal sustentada sobre individuos libres e iguales se encuentra abocada a tensiones de muy distinto tipo, fundamentalmente tensiones sociales derivadas de la lucha de todos contra todos y de la ruptura con una sociedad tradicional basada en lazos económicos, sociales, políticos y culturales que hacían hincapié en el grupo frente al individuo. Para evitar el desorden social previsible en una sociedad individualista, los liberales reivindican el papel arbitral del Estado para neutralizar los efectos de dicho desorden social.

$Y$ si bien, el Estado cumple un papel mínimo como garante neutral del desenvolvimiento de los individuos estableciendo un campo de juego y unas reglas iguales para todos, lo cierto es que, desde el punto de vista social, el sistema liberal se mostró muy inestable, a medida que el proceso de industrialización rompió con la economía tradicional, agrupando a los individuos en ciudades y generando nuevos lazos sociales en el ámbito del trabajo.

La existencia de grupos sociales con intereses antagónicos (burguesía y proletariado) ponía en cuestión la vieja doctrina sobre la autorregulación del sistema económico y social, doctrina mantenida por los primeros teóricos del liberalismo económico, y generaba una inquietud sobre la estabilidad y mantenimiento del nuevo sistema social individualista.

Claro que hasta las crisis económicas de fin del siglo XIX, la competencia colonial de los Estados europeos y las nuevas doctrinas nacionalistas que refuer- 
zan el papel de la comunidad sobre el individuo no se lleva a cabo un intento de reformular el modelo liberal a partir del fortalecimiento del Estado.

El Estado en los escritores neorrománticos del último tercio del XIX ya no sería un Estado mínimo, una maquinaria destinada a facilitar una teórica competencia entre los individuos, sino que cumpliría un papel fundamental como racionalizador de la estructura productiva, controlando y organizando las tendencias centrífugas de los intereses de los individuos, poniéndolas al servicio de un interés moral superior, la comunidad definida por el propio Estado.

En sus orígenes, el corporativismo fue una respuesta de la sociedad tradicional del Antiguo Régimen a las consecuencias de la revolución liberal y el inicio del capitalismo.

La disolución de la vieja sociedad fue considerada por los grupos privilegiados, la nobleza y las Iglesias, junto con la burocracia del Antiguo Régimen como un grave peligro para el mantenimiento de sus intereses y el control económico, social y político y cultural existente desde hacía siglos.

Ello explica la reformulación social de la vieja sociedad mediante el corporativismo concebido como una doctrina que defendía una sociedad jerárquica organizada en torno a las asociaciones intermedias, familia, municipio y corporaciones.

Este corporativismo social que entendía la sociedad como un ente orgánico con vida propia e independiente de los individuos, se completa con un nuevo concepto de Estado-Nación alternativo al Estado mínimo liberal y que concita todas las energías sociales en su seno, a través de una misión moral que debe realizar en la historia.

Este Estado encarna a la nación y es la fuente de toda ley. Por consiguiente a una noción de corporativismo social, le sigue el corporativismo político, que apoyándose en la vinculación y dependencia del hombre respecto a su contexto social, afirma la subordinación del individuo al Estado, representante del Todo colectivo.

La opción corporativa romántica de principios del siglo XIX, fue desplazada muy pronto por el modelo social, político y económico liberal triunfante a partir de los años 30 del siglo XIX, arrumbando el esquema defensivo del corporativismo romántico, pero en el último tercio del siglo XIX la sociedad liberal entra en una profunda crisis cuyos ejes esenciales fueron: una política económica proteccionista que asignaba al Estado un papel tuitivo de la economía nacional; el crecimiento del movimiento obrero y sus organizaciones sociales y políticas que suponían una contestación al modelo liberal y generan miedo entre las clases dirigentes europeas; el proceso de democratización política y social reflejado por el sufragio universal masculino, y la cultura de masas posibilitada por la alfabetización universal; la extensión de un nacionalismo esencialista que ponía el énfasis en la jerarquización social y en un modelo político autoritario antiliberal y antiparlamentario, y finalmente, la renovación del pensamiento en el marco del neorromanticismo que recupera parte de los elementos fundamentales del romanticismo de principios de siglo y rechaza las bases ideológicas de la ilustración y el liberalismo. El agotamiento del viejo 
modelo ideológico ilustrado-liberal que había dominado el escenario europeo desde el siglo XVIII trajo consigo el declive del liberalismo y conservadurismo clásicos, a favor de una conservadurismo radical «en cuya perspectiva el engrandecimiento de la nación, entendida como organismo colectivo, ocupaba el lugar prioritario" ${ }^{1}$.

Todo ello explica los debates que se producen en Europa dentro de la clase dirigente burguesa, con el fin de revisar los supuestos doctrinales del liberalismo indivieualista y la búsqueda de nuevas alternativas sobre el papel del Estado y la Sociedad, los remedios a los conflictos sociales y al crecimiento de las organizaciones obreras, o la búsqueda de nuevos modelos políticos diferentes del parlamentarismo, el sistema de partidos y la democratización política.

La percepción de las élites en el poder sobre la necesidad de introducir reformas sociales era algo generalizado; la idea de la miseria obrera conocida mucho mejor por los nuevos estudios de la sociología naciente y la convicción de la necesidad de hacer frente, mediante una política social estatal, al socialismo y anarquismo en ascenso, llevaron casi inevitablemente a una parte de la intelectualidad burguesa a debatir primero y a proponer en los Parlamentos nacionales después, toda una batería de medidas sociales que significaron el inicio del reformismo de Estado y el fin del viejo modelo estatal liberal.

A partir de aquí, la recuperación del corporativismo como alternativa a los conflictos sociales crecientes encontró eco en un Estado cada vez más intervencionista que había abandonado el dogma liberal del abstencionismo económico y social.

En definitiva, el corporativismo se constituyó en una alternativa de orden social basada en la gestión colectiva del conflicto a través de la armonía de clases gestionada por un Estado intervencionista.

Por otra parte, asistimos igualmente al nacimiento del catolicismo social que aspiraba a recuperar espacios públicos que el viejo liberalismo y la enemistad de las ideologías obreras le habían negado; y junto a él, a la reelaboración de propuestas políticas nacionalistas y autoritarias que defienden un sistema político basado en "los intereses" y no en los planteamientos liberales clásicos.

El nuevo pensamiento corporativista de fines del siglo XIX no deseaba volver a la Sociedad y los principios del Antiguo Régimen, excepto en el caso del modelo corporativo católico, sino más bien frenar la desintegración de la sociedad liberal oligárquica amenazada por la extensión del movimiento obrero y por el alcance de la democratización política y social que se presenta como un proceso imparable, ligado al crecimiento de una nueva clase media alfabetizada y muy numerosa.

En este período, contamos, en consecuencia, con dos modelos de corporativismo social: el modelo católico, tradicional, ligado al antiliberalismo, a la idealización de la sociedad del Antiguo Régimen y a la defensa de los intereses

1. González Cuevas, Pedro C., Historia de las Derechas españolas. De la llustración a nuestros dias, Madrid, 2000, pp. 188. 
de la Iglesia católica, amenazada por el proceso de secularización, al que se añade la hostilidad hacia las ideologías del movimiento obrero organizado; y otro modelo corporativo, que en parte se presentaba como defensivo respecto al impulso democratizador e igualitario, y en parte, asume un papel modernizador del orden social y económico frente a los fracasos del liberalismo clásico. Papel modernizador que se manifiesta en la nueva doctrina sobre el Estado intervencionista en el campo económico y social como conciencia colectiva y expresión del interés general de la nación y que representará el capitalismo de Estado.

La segunda crisis del liberalismo político-social ocurrida tras la Primera Guerra Mundial que provocó la aparición de doctrinas totalitarias sobre la Sociedad y el Estado, a partir de las reflexiones de escritores del siglo XIX, junto con la catástrofe económica del año 29 que pareció el fin del capitalismo individualista, marcó un nuevo momento corporativo aunando una concepción social que rechazaba la lucha de clases y el individualismo liberal y una concepción económica nacionalista en el marco de una sociedad estructurada en corporaciones controladas por el Estado.

Esta respuesta a los desafíos sociales provenientes del capitalismo y del avance del movimiento obrero organizado supone de nuevo poner el énfasis en el concepto de equilibrio o el orden social y en el papel del Estado como intermediario con los individuos organizados en corporaciones, convertidos en el sistema fascista en simples instrumentos de la voluntad estatal expresada por el líder y el Partido único.

Tras la Segunda Guerra Mundial y la derrota de los regímenes totalitarios y autoritarios, el concepto de pluralismo social y político se impone en el marco de una sociedad basada en la representación individual. Pero esto no significó la vuelta sin más a los viejos esquemas liberales de antes del conflicto bélico, ya que en numerosos países, singularmente de Europa, el papel del Estado continuó siendo relevante tanto en el campo económico, a través de una economía mixta, como en el campo social, a partir de la introducción desde el pensamiento socialdemócrata del concepto de Estado del Bienestar en los países del norte de Europa.

Si tras el interés de Bismarck por la política social, seguido por los círculos conservadores de poder europeos se escondían motivaciones reaccionarias que pretendian desactivar el movimiento obrero naciente, para evitar por arriba, una revolución desde abajo, las reformas posteriores a la Segunda Guerra Mundial obedecen a planteamientos muy diferentes.

Para los nuevos gobiernos laboristas y socialdemócratas que se estrenan en el poder en la posguerra, todo parte de un nuevo concepto de ciudadanía y un nuevo modelo de Estado. Para la socialdemocracia europea, la ciudadanía contaba con tres componentes: "el civil, el político y el social. Los tres ligados... habían discurrido divorciados... hasta ser recuperados cada uno en su siglo, los derechos civiles en el XVIII, los políticos en el XIX y los sociales en el XX. El 
impulso moderno hacia la igualdad social representaba la última fase de una evolución de la ciudadanía....”2.

La política social, centro del nuevo Estado redistribuidor, cumplía igualmente un papel de evitar o limitar al menos el conflicto social, el desequilibrio dentro de la sociedad construyendo un nuevo orden y una nueva armonía basada en la solidaridad social.

Una solidaridad social garantizada por el Estado que conseguía un pacto o acuerdo entre las clases poseedoras y las clases trabajadoras, asegurando a éstas una transferencia de recursos, a cambio de su integración y la aceptación de las vías de las reformas dentro de un modelo político liberal-democrático.

Es en este terreno del Estado redistribuidor organizado en torno a un acuerdo de solidaridad social entre clases en el marco de un modelo político democrático como hay que entender la aparición de las teorías neocorporativistas, sus diferencias y sus similitudes respecto al viejo corporativismo del siglo XIX $y$ primer tercio del siglo $\mathrm{XX}^{3}$.

Inicialmente, por lo tanto, el neocorporativismo responde a los planteamientos de una sociedad muy diferente, no es la sociedad liberal individualista $y$ oligárquica del siglo XIX, ni la sociedad totalitaria o autoritaria del XX, es una sociedad de clases medias organizada en grupos de intereses muy diversos con un Estado redistribuidor de recursos y jugando un papel activo en el campo social.

En realidad, las propuestas neocorporativistas representan, por una parte, la continuidad del pensamiento corporativista del siglo XIX, obviamente alejado de su carácter autoritario, y por otro lado, la búsqueda de nuevas fórmulas sociales y políticas que resuelvan los problemas del liberalismo clásico sobre la base de un modelo de democracia de consenso, alejado del sistema representativo y partidario tradicional.

\section{ORIGENES DEL MODELO CORPORATIVO EN EUROPA. ROMANTICISMO Y ANTILIBERALISMO}

La concepción corporativa nace, como es sabido, en el seno del romanticismo político alemán a principios del siglo XIX, de la mano de escritores y pensadores antiliberales contrarrevolucionarios ${ }^{4}$.

2. BALDWIN, Peter, La politica de Solidaridad Social. Bases sociales del Estado de Bienestar europeo 18751975, Madrid, 1992, pp. 21 y ss.

3. Existen numerosos estados de la cuestión sobre el neocorporativismo, citaré solamente algunos: POLLAK, Michael y RUFFAT, Michèle, "Le Neocorporatisme: Ruptures et Continuités», Bulletin de IInstitut d'Histoire du Temp Present, n. ${ }^{\circ}$ 29-30, Paris, 1987; SOLE, Carlota (ed.), "Neocorporatisme", Revista Papers, n. ${ }^{\circ}$ 24, Barcelona, 1983; GINER, S. y PÉREZ, M. (eds.), "Corporatismo", Revista Española de Investigaciones Sociológicas, $n .{ }^{\circ} 31$ (1985); SANZ MENÉNDEZ, L. (ed.), "Representación de intereses y políticas públicas: ¿Corporatismo o Pluralismo?», Revista Zona Abierta, n. ${ }^{\circ} 67-68$ (1994).

4. Sobre este mismo tema publiqué un artículo en 1984, PERFECTO, M. A., "Panorama de la idea corporativa en Europa hasta los años 30 del siglo XX", Revista Studia Historica. Historia Contemporánea, vol. II, n. 4 (1984), pp. 157-169. 
El perfil sociológico de los corporativistas y contrarrevolucionarios europeos refleja una mayoría de burócratas del Antiguo Régimen ligados a la corte prusiana y a las universidades alemanas, es el caso de los hermanos Schlegel, Adam Müller, Joseph Gorres; pequeños aristócratas, defensores del particularismo local alemán, como Justus Moser; partidarios de la corte católica austriaca como Frederic de Gentz, secretario del Congreso de Viena y colaborador del canciller austriaco Metternich, o nobles italianos y franceses como F. Renée de Chateaubriand, Louis de Bonald, el campeón de la Restauración en Francia, o Joseph de Maistre ${ }^{5}$.

En definitiva, el grupo que elabora una alternativa social al liberalismo revolucionario estaba integrado por la nobleza y sus grupos sociales afines, las Iglesias, sobre todo la católica, y la burocracia del Antiguo Régimen.

El modelo político-social romántico refleja el rechazo de la aristocracia europea y la Iglesia al liberalismo político, económico y social y su añoranza por la vieja sociedad del Antiguo Régimen.

Así como la revolución liberal constituyó un fenómeno generalizado en toda Europa, a partir del último tercio del siglo XVIII, también el pensamiento contrarrevolucionario tuvo un carácter general europeo ante el triunfo de las nuevas ideas con la Revolución Francesa.

Ya en época tan temprana como 1790 se comienza a teorizar sobre el sistema político del Antiguo Régimen frente al Liberalismo triunfante, considerado un desastre para la sociedad moderna. Eso explica la obra del inglés Edmund Burke, Consideraciones sobre la Revolución Francesa ${ }^{6}$ obra que gozó de una importante popularidad, reflejada en la inmediata traducción a la mayoría de los idiomas europeos.

Consideraciones sobre la Revolución Francesa se convirtió en la Biblia de la contrarrevolución, desde el momento en que presenta la Revolución Francesa como un fenómeno destructor de la Sociedad y del Estado.

Como Burke, el saboyano Joseph De Maistre y el francés Louis de Bonald opinan que la Revolución es el resultado de un castigo divino contra la filosofía y el ateismo.

5. En castellano contamos con las obras de MULLER, Adam, Elementos de Politica, Madrid, 1977 (la primera edición española es de 1935); MOSER, Justus, Escritos escogidos, Madrid, 1984; BONALD, Louis de, Teoria del poder político y religioso, Madrid, 1988; MAISTRE, Joseph de, Consideraciones sobre Francia, Madrid, 1955; y del mismo autor Las Veladas de San Petersburgo, Madrid, 1966. Un ensayo interesante sobre Bonald es el de PALACIOS, L. E., "Bonald o la constitución natural de las sociedades", Revista de Estudios Políticos, n. ${ }^{\circ} 25$ (1949); CORTE, M., La filosofía política de Bonald, Arbor, n. ${ }^{\circ}$ 20, Madrid, 1951, pp. 191-211. Igualmente es de destacar TruYoL, A., "Dos analistas críticos clásicos de la Revolución Francesa: Burke y De Maistre", Revista Anales de la Real Academia de Ciencias Morales y Politicas, 42 (1990), pp. 111-122.

6. En castellano disponemos de dos obras de Burke, Reflexiones sobre la Revolución Francesa, con traducción y prólogo de Enrique Tierno Galván, Madrid, 1978 y Textos Políticos, México, 1984. Además de una pequeña, pero útil biografía de Burke, la de MACPHERSON, C. B., Burke, Madrid, 1980. 
Frente a la concepción racionalista ilustrada y liberal y la razón universal, los contrarrevolucionarios oponen el valor de la irracionalidad, el "prejuicio» en frase de Burke, los valores de los pueblos, la originalidad esencial de cada nación y cada cultura, producto de la herencia histórica.

Frente a la doctrina del contrato social defienden la excelencia de los lazos generacionales que ligan a los hombres entre sí; y finalmente, frente a la idea de progreso ilimitado del espíritu humano oponen la superioridad de la experiencia de los siglos pasados.

Los ejes fundamentales del romanticismo son los siguientes: 1) La idealización de los lazos afectivos que uniendo a los hombres entre sí forman la sociedad humana; 2) La consideración del Estado como un «ente» con existencia propia e independiente de los individuos, que define y dirige la sociedad; y 3) El mantenimiento de una visión historicista que identifica Sociedad y Nación?

La idealización de los lazos afectivos que unen a los hombres entre sí es capital para la formación social y política de los románticos. Mientras que la concepción sobre las relaciones sociales de los filósofos ilustrados hacía hincapié en el individualismo de los seres humanos, razonables por su origen y animados por los mismos ideales de libertad e igualdad; los románticos dan prioridad a los lazos de todo tipo que unen al individuo con la colectividad, en consecuencia, el organismo social se convierte en el elemento fundamental de su reflexión sobre la sociedad.

La sociedad, y en esto siguen al inglés Burke, se forma por la continuidad histórica de generaciones en una nación concreta (territorio limitado, tradiciones y costumbres propias y una lengua, religión y raza, forjadas a lo largo de los siglos).

En el núcleo básico del romanticismo político alemán sobresale la consideración de la subordinación del individuo a la sociedad en la que nace y el desarrollo de un nuevo concepto de Nación, muy diferente al liberal de la Revolución Francesa, que plantea la fusión de sociedad y nación, presentando a ésta, no como un proyecto voluntario realizado por individuos libres e iguales en derechos, sino como una realidad esencial, genética, histórica y cultural, que se impone al individuo.

Si para los ilustrados, el Estado se consideraba un mal necesario, algo transitorio, destinado a asegurar las funciones de policía y el respeto a los derechos individuales; para los románticos, en cambio, el Estado se convierte en un ser

7. Algunas obras clásicas sobre el romanticismo político alemán son las de DROZ, J., L'Allemagne et la Revolution Française, Paris, 1949; Le romantisme politique en Allemagne, Paris, 1963; Le romantisme allemand et l'État, Paris, 1966. Igualmente siguen siendo útiles los libros de AYRAULT, R., La gènese du romantisme allemand, Paris, 1970; SPENLE, J. E., La pensée allemande de Luther à Nietzsche, Paris, 1967. Sobre la recepción de la Revolución francesa en Alemania contamos con una obra más reciente, GllLi, Marita (ed), La réception de la Revolution Française dans le pays de langue allemande, Paris, 1986. Un buen resumen en español sobre el romanticismo político y la contrarrevolución, el de ABELLÁN, J., "Reacciones ante la Revolución Francesa (Edmund Burke, los pensadores alemanes y De Maistre y De Bonald)», en VAlLESPín, F. (ed), Historia de la Teoría Politica, vol. 5 , Madrid, 1993, pp. 14-81. 
de esencia superior que encarna la nación y es la fuente de toda ley, dirigido por el rey, cabeza e imagen viva de la nación.

La filosofía romántica confiere al Estado una existencia propia, natural, orgánica, independiente de la voluntad de los individuos.

Desde este punto de vista, el Estado-Nación se convierte en un ser vivo, un organismo similar al biológico, que evoluciona según sus leyes propias, marcadas por el espíritu «nacional».

En consecuencia, la reelaboración de la concepción estamental del Antiguo Régimen es patente en la estructuración social corporativa defendida por el pensamiento romántico.

En el romanticismo alemán encontramos por lo tanto, una doctrina sobre el Estado que se identifica con la Sociedad ${ }^{8}$; También una doctrina social que concibe a ésta como un organismo vivo forjado a lo largo del tiempo por la solidaridad de las distintas generaciones y basado en una jerarquización social a través de las llamadas agrupaciones naturales, y una doctrina sobre la Nación como una comunidad histórica asentada por una serie de elementos (territorio limitado, tradiciones y costumbres determinadas y una lengua, religión y raza forjadas a lo largo de los siglos) ${ }^{9}$.

De la fusión de estos tres elementos ideológico-políticos nacerán las bases del pensamiento conservador europeo ${ }^{10}$. Pensamiento inicialmente antiliberal y contrarrevolucionario que, a lo largo del siglo XIX, se actualizará a partir de la aceptación de determinadas tesis liberales.

Entre los autores que impulsaron la noción del Estado «orgánico» se hallaron, como hemos comentado, filósofos tan destacados como Fichte, Schelling o el propio Hegel.

Así, si para Schelling el Estado es un producto de la naturaleza organizada donde cada parte sólo existe relacionada con el Todo, lo cual genera el equilibrio del sistema; igualmente, son de destacar por su importancia, las reflexiones sobre el Estado «orgánico», jerarquizado y antiigualitario del gran filósofo del romanticismo organicista, el prusiano Adam Müller, amigo de Frederic de Gentz. Adam Müller ha pasado a la historia como un gran autor contrarrevolucionario, teórico de la organización tradicional de la sociedad y de los intereses de la aristocracia terrateniente.

8. HEGEL, G., Filosofía de la Historia, Madrid, 1953, pp. 91 y ss.: «El Estado es la realidad en la cual el individuo tiene y goza su libertad... El Estado es, por tanto, el centro de los restantes aspectos concretos: derecho, arte costumbres... El Estado es la vida moral realizada. Pues el Estado es la unidad de la voluntad universal y esencial con la subjetiva y esto es la moralidad...".

9. FICHTE, J. G., Discursos a la Nación alemana, Madrid, 1985, p. 235: "En primer lugar, y ante todo, digamos que las fronteras primeras, originarias y realmente naturales de los Estados son, sin duda alguna, sus fronteras internas. Quienes hablan la misma lengua están unidos entre sí por una serie de lazos invisibles, simplemente por naturaleza, y mucho antes de cualquier artificio humano... pertenecen al conjunto y constituyen por naturaleza un todo único e inseparable...».

10. Son de utilidad entre otras las obras de KIRK, Russel, La mentalidad conservadora en Inglaterra y Estados Unidos, Madrid, 1956; HONDERICH, Ted, El conservadurismo, un análisis de la tradición anglosajona, Barcelona, 1993; NISBET, Robert, Conservadurismo, Madrid, 1995. 
La teoría estatal de Müller parte del carácter social del ser humano, forjado a lo largo del tiempo a través de la solidaridad generacional. El Estado identificado con la Sociedad es la suma de los intereses humanos fusionados en un Todo orgánico ${ }^{11}$. Este Estado "orgánico», antiigualitario y jerarquizado, une las diferentes categorías sociales, desde la célula base, la familia, promoviendo la armonía social.

En el pensamiento de Müller encontramos los principales elementos del pensamiento corporativo: la noción de la sociedad como un organismo que nace, se desarrolla y puede morir; la subordinación del individuo a la colectividad expresada por el Estado, y el carácter jerárquico de la sociedad, organizada en agrupaciones inferiores como la familia ${ }^{12}$.

En realidad, el corporativismo se planteó como una respuesta defensiva a la desaparición de la vieja sociedad del Antiguo Régimen, pero fue también una de las respuestas a las inquietudes del pensamiento político y sociológico del siglo XIX sobre las condiciones del "orden social» y el mantenimiento del necesario equilibrio en una sociedad en evolución y cambio constante.

Desde este punto de vista, el pensamiento corporativo se inscribe en el campo de la reflexión de las relaciones entre el Estado y la Sociedad Civil, cuyos polos extremos estarían formados, por un lado, por la doctrina anarquista que pretende la desaparición del Estado, y por otro, por la noción del Estado autoritario o totalitario, como máxima expresión de la eficacia social, técnica y económica.

El triunfo de modelo liberal, más o menos moderado, pero siempre individualista, a partir de los años 30 del siglo XIX, eclipsó los planteamientos organicistas y corporativos del romanticismo político alemán. Los elementos que favorecieron ese cambio fueron:

En primer lugar, la transformación económica generada por el gran capitalismo con una importante mejoría en las economías de los grandes Estados y la difusión de la política económica proteccionista.

En segundo lugar, el crecimiento de la contestación obrera nucleada en torno a partidos y sindicatos socialistas y anarquistas que se convierten en referentes de un sistema de valores radicalmente antiliberal.

En tercer lugar, los inicios de una cultura de masas posibilitada tanto por la difusión de los medios de comunicación, como por la extensión del sistema educativo y la alfabetización universal.

11. MüLler, Adam, Elementos de Política..., pp. 43 y ss.: "El Estado no es una institución artificial... sino que es el Todo de esa misma vida, necesaria en cuanto se dan hombres, ineludible, fundada en la naturaleza del hombre... no es posible pensar al hombre fuera del Estado... nada humano existe fuera del Estado".

12. Ibidem., pp. 66 y ss.: «La alianza eterna de los hombres entre si que designamos como Sociedad - Estado es... de carácter doble: una alianza de los hombres que gozan de la tierra en la misma época... una alianza de las generaciones pasadas con las presentes y las que siguen». 
En cuarto lugar, el impulso del colonialismo y su ideología básica, el imperialismo, que junto a un nuevo nacionalismo agresivo y xenófobo se extiende por todo el continente.

En quinto lugar, aunque no menos importante, la continuación del proceso hacia la consecución de la democratización política, en forma de la aprobación del sufragio universal masculino que obligará a transformar los viejos partidos de élites en partidos de masas.

Y en sexto lugar, el agotamiento del viejo modelo ideológico ilustrado-liberal que había dominado el escenario europeo desde el siglo XVIII. Y que trajo consigo el declive del liberalismo y conservadurismo clásicos, a favor de un conservadurismo radical «en cuya perspectiva el engrandecimiento de la nación, entendida como organismo colectivo, ocupaba el lugar prioritario ${ }^{13}$.

Ello explica una nueva actitud en el pensamiento europeo de rechazo a la Ilustración y sus valores y la recuperación de elementos esenciales en el viejo romanticismo de comienzos del siglo XIX.

Como muy bien señalaba Stuart H. Hughes "no es difícil creer que los escritores del decenio de 1890-1900 o de principios del siglo siguiente sintieran que estaban remontándose medio siglo atrás para restituir el honor a aquellos valores de la imaginación que sus inmediatos predecesores habían escarnecido»" ${ }^{14}$.

La corriente de pensamiento neorromántica de finales del XIX no significó la pura restauración de la ideología romántica de principios de siglo, sino más bien el rechazo de la visión positivista de la Ilustración, para ello recuperan elementos de comprensión del mundo y la sociedad como la subjetividad, el irracionalismo, el gusto por la historia y la religión, el rechazo de las instituciones representativas, la defensa de un modelo de nacionalismo integral, directamente emparentado con el nacionalismo esencialista germánico, el concepto de élite y jerarquía social, etc.

En estos años se extiende por toda Europa, tanto en medios conservadores, como católicos, el debate sobre el Estado intervencionista en cuestiones sociales y el abandono de la vieja concepción liberal abstencionista.

La percepción de las élites en el poder sobre la necesidad de introducir reformas sociales era algo generalizado; la idea de la miseria obrera conocida mucho mejor por los nuevos estudios de la sociología naciente y la convicción de la necesidad de hacer frente, mediante una política social estatal, al socialismo y anarquismo en ascenso, llevaron casi inevitablemente a una parte de la intelectualidad burguesa a debatir primero y a proponer en los Parlamentos nacionales

13. González Cuevas, Pedro C., Historia de las Derechas españolas. De la llustración a nuestros dias, Madrid, 2000, p. 188.

14. HuGHES, H. Stuart, Conciencia y Sociedad. La reorientación del pensamiento social europeo 1890-1930, Madrid, 1958, pp. 26 y ss. Véase también STERN, Fritz, Politique et désespoir. Les ressentiments contre la modernité dans l'Allemagne prehitlerienne, Paris, 1990. 
después, toda una batería de medidas sociales que significaron el inicio del reformismo de Estado y el fin del viejo modelo estatal liberal ${ }^{15}$.

A partir de aquí, la recuperación del corporativismo como alternativa a los conflictos sociales crecientes encontró eco en un Estado cada vez más intervencionista que había abandonado el dogma liberal del abstencionismo económico $y$ social.

Por otra parte, asistimos igualmente al nacimiento del catolicismo social que aspiraba a recuperar espacios públicos que el viejo liberalismo y la enemistad de las ideologías obreras le habían negado; y junto a él, a la reelaboración de propuestas políticas nacionalistas y autoritarias que defienden un sistema político basado en "los intereses» y no en los planteamientos liberales clásicos.

\section{LA FORMACIÓN DEL CORPORATIVISMO EN ESPAÑA. REFORMISMO SOCIAL Y ORGANICISMO}

\section{a) Los planteamientos del reformismo liberal krausista: Intervencionismo estatal y organicismo social}

En el último tercio del siglo XIX, encontramos en España dos planteamientos que servirán de base al nacimiento de la legislación social: el organicismo como concepción filosófica sustentadora de un armonicismo social, y la noción del Estado tutelar que interviene en el campo social y económico. Estos dos elementos se integrarán, junto con las alternativas del catolicismo social, en los orígenes doctrinales del corporativismo español.

La sustitución en el Gobierno español del Partido Conservador por el Liberal en los años 80 supuso el comienzo de un proceso de reformas sin precedentes que abarcaron el campo jurídico (la aprobación de los códigos de leyes, juicio por jurados), ampliación de las libertades (libertad de imprenta de 1883, Libertad de Asociaciones de 1887), el campo político (sufragio universal masculino

15. Para el caso español, hay un estado de la cuestión de MONTERo, Feliciano, «De la beneficencia a la reforma social. Los orígenes de la política social del Estado: estado de la cuestión, fuentes y archivos", Revista Espacio, Tiempo y Forma-Historia Contemporánea, t. 7, serie V (1994). Además de excelentes estudios, entre ellos destacamos desde el estudio inicial de IGLESLAS, $M{ }^{a}{ }^{a}$ Carmen y ELORZA, Antonio, Burgueses y proletarios. Clase obrera y reforma social en la Restauración, Barcelona, 1973, hasta los de MONTERo, Feliciano, "La polémica sobre el intervencionismo y la primera legislación obreta en España, 1890-1900", Revista de Trabajo, n.o 59-60, y 61-62 (1980), pp. 121-165, y una parte de su tesis sobre El primer catolicismo social y la Rerum Novarum en España, Madrid, 1983; DE IA CALle VelasCo, M. D., La Comisión de Reformas Sociales, 1883-1903. Politica social y conflicto de intereses en la España de la Restauración, Madrid, 1989. PALACIO MORENA, J. I., La institucionalización de la reforma social en España (1883-1924). La Comisión y el Instituto de Reformas Sociales, Madrid, 1988. El mismo autor editó sendos volúmenes en el Centenario del Instituto de Reformas Sociales titulados: La construcción del Estado Social. En el Centenario del Instituto de Reformas Sociales, Madrid, 2004, y La Reforma Social en España. En el Centenario del Instituto de Reformas Sociales, Madrid, 2004. GUILLÉN, A., El origen del Estado de Bienestar en España (1876-1923), Madrid, 1990. Desde el campo del Derecho conviene resaltar las aportaciones de Palomeque, Manuel C., Derecho del trabajo e ideologia. Medio siglo de formación ideológica del Derecho español del trabajo, 1873-1923, Madrid, 1980; MONTOYA, Alfredo, Ideología y lenguaje en las primeras leyes laborales de España, Madrid, 1975. 
en 1890), y por supuesto, el social (creación de la Comisión de Reformas Sociales en 1883).

El debate sobre el intervencionismo o no del Estado en cuestiones sociales, en línea con las propuestas teóricas europeas de aquellos años, y la política social de la Alemania bismarckiana se reflejará en tres grupos diferentes: el grupo liberal-republicano krausista, el grupo conservador y los católicos sociales.

La nueva sensibilidad sobre la llamada cuestión social tiene que ver con una serie de factores: desde la crisis económica de los 80 en el campo, la extensión de la industrialización y su consecuencias sociales, la expansión del anarquismo y el socialismo que condujeron al nacimiento del sindicalismo moderno y el nacimiento del Partido Socialista Obrero Español, o las grandes huelgas y manifestaciones de comienzos de los 90 que conmovieron a la burguesía industrial española.

El grupo liberal-republicano krausista impulsor, junto con el catolicismo social y el conservadurismo, del nacimiento de la política social en España, estaba integrado por una burguesía intelectual, vinculada a la Universidad, centrada sobre todo en el campo del Derecho, Medicina e Ingeniería ${ }^{16}$. De los 17 miembros que compusieron la Comisión Central de Reformas Sociales en 1883, núcleo del reformismo social español de los 80 y 90, 11 estaban vinculados a la carrera de Derecho, muchos de ellos catedráticos de la Universidad Central de Madrid.

Por otra parte, su actividad no se reducirá al ejercicio de la profesión, la mayoría ejercerá, además, diversos cargos políticos durante el período y actividades de difusión de la ideas a través de los mecanismos característicos del siglo XIX: la Academia de Ciencias Morales y Políticas, Ateneos, prensa, etc.

En definitiva, el grupo krausista representaba a las élites burguesas del poder establecido que se acercaron al mundo obrero desde una óptica paternalista y de desconfianza ${ }^{17}$.

La Comisión de Reformas Sociales creada en 1883 para tratar la situación de la clase obrera -e integrada mayoritariamente por liberal-krausistas-, se esforzó, afirma la profesora De La Calle, en «afianzar los estudios sociales... Defensora

16. Sobre la relación de la burguesía intelectual española, la política y el reformismo social puede consultarse VILlaCORTA BAÑOS, Francisco, Burguesía y cultura. Los intelectuales españoles en la Sociedad Liberal, Madrid, 1980, en especial, las páginas 80 y ss.

17. Sobre el grupo krausista de la Comisión de Reformas Sociales puede consultarse tanto el artículo de la profesora DE LA CALLE VelaSCO, Dolores, "La Comisión de Reformas Sociales: De la represión al análisis de la conflictividad social», Revista Studia Historica-Historia Contemporánea, vol. II, n. ${ }^{\circ}$ 4, pp. 13-41, Universidad de Salamanca, Salamanca, 1984, como su libro sobre el mismo tema, La Comisión de Reformas Sociales..., Madrid, 1989. Según la autora: «El objetivo del grupo es rectificar los abusos del capitalismo con reformas insuficientes. Pretenden un cambio de valores en la sociedad, sin tocar las estructuras, desde la posición intermedia de unos intereses tan dispares como los de la oligarquía y el mundo obrero propiciadora de una armonía imposible o utópican, Ibidem, p. 32. 
de un intervencionismo más social que estatal, otorgaba al Estado la función tutelar de amparar a los débiles y corregir los desequilibrios sociales» ${ }^{18}$.

El pensamiento de este grupo intelectual reformador se nutría mayoritariamente de la filosofía krausista, una filosofía introducida en España por Julián Sanz del Río (1814-1869), catedrático de Historia de la Filosofía de la Universidad Central de Madrid, a partir de la obra de un filósofo postkantiano, el alemán Karl Ch. Krause (1781-1832) y de su discípulo Ahrens ${ }^{19}$.

Esta filosofía se extendió mediante seguidores como Francisco Giner de los Ríos, fundador de la Institución Libre de Enseñanza, Gumersindo de Azcárate, Vicente Santa María de Paredes o Adolfo Posada y muchos otros, que jugarán un papel fundamental en la construcción de un modelo de reformismo social y educativo de raíz liberal de gran influencia en España, de ahí el nombre del movimiento español conocido como krausismo ${ }^{20}$.

Para el krausismo, la sociedad es un organismo, un conjunto de órganos ordenados sistemáticamente que constituyen y representan una unidad vital. De donde se deduce que la soliearidad es un factor sustancial en la sociedad humana, una solidaridad que se expresa mediante la cooperación pacífica de todos sus miembros para el cumplimiento de las distintas finalidades sociales.

El organicismo krausista rechaza el automatismo social de raíz biologicista, defendiendo, en cambio, la libre iniciativa para transformar las instituciones sociales, es por ello, por lo que el krausismo se inscribe dentro del liberal-republicanismo reformador.

El krausismo español inspiró y participó en todos los proyectos de reformas sociales y de legislación obrera que se llevaron a cabo en España a partir de unos principios que ponían el énfasis en las reformas frente a la revolución; en una concepción armónica en las relaciones de capital y trabajo; en la defensa del sistema económico capitalista; en la necesidad de una reforma integral mediante la educación del hombre y la sociedad; y finalmente, en una actitud moralizante respecto a la clase obrera.

Dentro de esta corriente muy relevante en la España del último tercio del siglo encontramos a Eduardo Pérez Pujol (1830-1894), catedrático de Derecho

18. De la CALle VelasCo, Dolores, "Sobre los orígenes del Estado Social en España", Ayer, n. ${ }^{\circ} 25$ (1997), p. 149.

19. Una obra reciente sobre Krause, QUEROL FERNÁNDEZ, F., La filosofía del derecho de K. Ch. Krause, Madrid, 2000.

20. A la filosofía social krausista se la define como "racionalismo armónico" y pretendía conciliar "la analítica de Kant, las aspiraciones reformadoras y humanitarias de Fichte, el panteísmo de Schelling y el sistema de nociones universales -categorías- de Hegel", en LóPEz MORILLAS, J. J., El Krausismo español, México, 1956, p. 31. Sobre este movimiento reformador español pueden leerse los libros de GIL CREMADES, J. I., El reformismo español. Krausismo, escuela histórica, neotomismo, Barcelona, 1969 y del mismo autor Krausistas y Liberales, Madrid, 1975; Díaz, Elías, La filosofía social del krausismo español, Madrid, 1973 así como el de GÓMEz MOLLEDA, M. ${ }^{2}$ Dolores, Los reformadores de la España Contemporánea, Madrid, 1966. 
Romano desde 1856 y más tarde rector de la Universidad de Valencia entre 1869 y 1873, ciudad en la que permaneció hasta su muerte ${ }^{21}$.

Pérez Pujol había tomado contacto con el grupo krausista madrileño en los años 50 y se adscribió desde entonces a esa filosofía social reformadora desde posiciones liberales, participando en el proceso revolucionario iniciado en 1868 y más tarde en una serie de actividades sobre la llamada "cuestión social» que sirvieron de base a la Comisión de Reformas Sociales y a la primera encuesta social española de 1884 que permitió conocer por primera vez la vida, el perfil y opiniones de una serie de agentes sociales y económicos en la España de fin de siglo.

Eduardo Pérez Pujol fue uno de los precursores que defendieron la restauración modernizada de los gremios como alternativa armonicista a los conflictos sociales, y en ese empeño por acabar con las raíces del conflicto social defendió la necesidad de la intervención tutelar del Estado, e incluso la formación de un Parlamento corporativo.

Ya en 1872 publicó un discurso titulado "La cuestión social en Valencia» donde desarrollaba las líneas maestras de un reformismo social basado en la superación del conflicto social mediante el armonicismo social, es decir, el principio de solidaridad del Estado y las instituciones que forman la sociedad ${ }^{22}$; la constitución de los jurados mixtos como fórmula de cooperación voluntaria de patronos y obreros para resolver sus diferencias; la creación de Sociedades cooperativas de producción, consumo y crédito -propuesta directamente inspirada en Owen-; la beneficencia privada y la instrucción obrera.

Además de estos planteamientos sociales que influirán, como hemos indicado, en la creación en 1883 de la Comisión de Reformas Sociales, Pérez Pujol avanza también otros elementos como la conveniencia de restaurar los antiguos gremios medievales, si bien adaptados a las nuevas circunstancias del capitalismo liberal.

Para él, los gremios debían ser sociedades voluntarias integradas por empresarios, oficiales y obreros para promover la concertación de los intereses industriales, creando un clima de armonía entre «fabricantes y obreros».

El gran reto del gremio era solucionar la llamada "cuestión social» a través del establecimiento de cauces orgánicos entre trabajadores y empresarios de esta manera, los excesos de la industrialización, el trabajo de mujeres y niños y,

21. La obra de Pérez Pujol ha sido estudiada por Romeu ALFaro, S., Eduardo Pérez Pujol. Vida y obra, Valencia, 1979 (reedición de 15 trabajos y prólogos de Pérez Pujol). Puede verse igualmente, mi artículo PERFECTO, M. A., "Introducción al pensamiento político y económico-social de Eduardo Pérez Pujol", Revista Provincia de Salamanca, n. 3 (mayo-junio, 1982), pp. 27-47. Desde una órbita muy conservadora justificadora de la dictadura franquista, el libro de FERNÁNDEZ DE LA Mora, Gonzalo, Los teóricos izquierdistas de la Democracia orgánica, Barcelona, 1985, pp. 71 y ss.

22. «El Estado, decía Pérez Pujol, es el órgano de relaciones del individuo con la sociedad como de las instituciones sociales entre sí... la sociedad ha de ser siempre producto de la asociación voluntaria... El Estado, tutor al presente de la sociedad en limitados órdenes, no debe olvidar que su poder es transitorio», en "La Sociología y la fórmula del Derecho", Discurso leído en el Ateneo de Valencia en 1875, en ROMeU Alfaro, S., Eduardo Pérez Pujol..., pp. 176 y ss. 
en definitiva "la miseria de unos y el fausto de otros» encontraría una respuesta adecuada consiguiendo la consolidación del orden social.

Los gremios, decía Pérez Pujol, deben servir para preparar el camino de los jurados mixtos y el régimen de participación de beneficios en la industria además de constituir instituciones de patronato y beneficencia.

Ahora bien en su pensamiento, los gremios no cumplirían únicamente una función de articulación social, de protección de los obreros y de eliminación de los conflictos sociales, sino que transformarían la vida política sobre la base de una estructuración gremial del Parlamento, es decir, el sufragio corporativo. De esa forma, toda persona que tuviera una profesión, un trabajo o una propiedad podría elegir a los diputados que correspondieran a su gremio ${ }^{23}$.

Años mas tarde, en 1889, Pérez Pujol matizaba su propuesta defendiendo la existencia de un Parlamento bicameral: el Congreso de los Diputados elegido por sufragio universal, y el Senado, por sufragio corporativo.

Eduardo Pérez Pujol fue importante no sólo como inspirador de los movimientos de reformas sociales de los años 80 y 90 del siglo XIX, origen de la primera legislación social española, sino también por la recuperación de algunos de sus planteamientos corporativos, en la década de los 20, por parte del ministro de Trabajo de la dictadura de Miguel Primo de Rivera, y más tarde, ministro de Justicia en la dictadura de Franco, Eduardo Aunós, autor intelectual del primer proyecto gubernamental de un sistema corporativo, próximo al fascismo italiano, que influirá más tarde en el modelo franquista ${ }^{24}$.

\section{b) Las propuestas sociales del conservadurismo español}

Junto con el krausismo, defensor de un intervencionismo estatal moderado y de una concepción «organicista» de la sociedad, conviene destacar el conservadurismo español representado por su líder Antonio Cánovas y sobre todo por los llamados regeneracionistas conservadores como Francisco Silvela, Eduardo Dato (autor de las primeras leyes sociales a comienzos del siglo XX) y Antonio Maura.

Para una parte del conservadurismo español era importante revisar los supuestos del liberalismo individualista en línea con las propuestas teóricas que se discutían en la Europa de entonces, desde la revisión de la economía clásica a cargo de la escuela histórica alemana (los "socialistas de cátedra") y la extensión

23. "La representación nacional, decía Pérez Pujol, no debe sustentarse sobre bases de movediza arena (como el régimen individualista del sufragio), sino sobre elecciones por gremios y clases...", en "El régimen electoral. Elecciones por gremios y por clases", Revista de España, Madrid, 1877, citado por Romeu Alfaro, S., Eduardo Pérez Pujol..., pp. 186 y ss.

24. Véase el folleto de Eduardo Aunós "La política social de la Dictadura", Madrid, 1944, pp. 59 y ss., donde lo presenta como el precursor de la doctrina corporativa española. Sobre la política social corporativa en la España de los años 20 puede leerse mi ensayo PerfeCto, Miguel Ángel, "Regeneracionismo y Corporativismo en la Dictadura de Primo de Rivera", en TUSELL, J.; MONTERO, F. y MARín, J. M. ${ }^{a}$ (eds), Las Derechas en la España Contemporánea, Barcelona, 1997, pp. 177-197. 
de las políticas proteccionistas, hasta la corriente "solidarista» de raíz francesa que defendía el principio de la "solidaridad natural» frente al principio de "la lucha por la vida", justificando así un nuevo concepto de Estado como elemento activo al servicio de un ideal social.

Por otra parte, sobre este grupo conservador influyen hechos tan notables como la recepción de la encíclica de León XIII Rerum Novarum en 1891, -si bien, la repercusión inicial de dicha encíclica no fue mury grande, ni entre los políticos conservadores, ni en el campo católico, según afirma Feliciano Montero_25 y la misma política social diseñada por el canciller alemán Bismarck con el fin de frenar el ascenso del socialismo en su país ${ }^{26}$.

Como muy bien señala el profesor Montero «La reforma social en España se plantea y avanza muy estrechamente vinculada al reformismo social europeo. Una minoría de la élite gobernante e intelectual española conoce las leyes e instituciones sociales que se están implantando en Alemania, Francia, Bélgica, y participa en las instancias internacionales promotoras de la reforma social... ${ }^{27}$.

El conservadurismo de fines deI XIX es decididamente partidario del Estado intervencionista en el campo social y económico y algunos de sus miembros como Francisco Silvela, defensores, igualmente, del sufragio corporativo ${ }^{28}$.

El intervencionismo conservador expresado por Antonio Cánovas del CastiIlo gira en torno a tres aspectos: en primer lugar, el proteccionismo económico; en segundo lugar, la necesidad de una legislación social obrera, en el marco de la libertad de contratación; y en tercer lugar, la necesidad de una contención de las acciones revolucionarias mediante la defensa del orden público ${ }^{29}$.

Desde este ángulo, el intervencionismo estatal en forma de leyes obreras cumple el objetivo político conservador de contrarrestar la revolución socialista, haciendo concesiones a los obreros para atraerlos a posiciones moderadas, aunque esas concesiones se alternarán con la represión cuando sea necesaria ${ }^{30}$.

25. MONTERO, F., "Rerum Novarum». Escriture, contenue et reception d'une Encyclique, École Française de Roma, 1997, p. 431.

26. Puede verse el artículo de MONTERO, F., "Conservadurismo y cuestión social», en TUSELL, J.; MONTERO, F. y MARÍn, J. M. (eds.), Las Derechas en la España Contemporánea, Barcelona, 1997, pp. 59-77.

27. MONTERo, F., "Conservadurismo y cuestión social" en TUSELl, J.; MONTERo, F. y MARÍN, J. M. ${ }^{\text {a }}$ (eds.), Las Derechas en la España Contemporánea..., p. 61.

28. Véase el artículo de PORTERO, Florentino, "El regeneracionismo conservador. El ideario político de Francisco Silvelan, en Tusel., J.; MONTERo, F. y MARín, J. M. ${ }^{2}$ (eds.), Las Derechas en la España Contemporánea..., pp. 45-58.

29. CÁNOVAS DEl CASTILlo, Antonio, "Por mi parte, opino que será más ventajoso a la larga, el concierto entre patronos y obreros, con o sin intervención del Estado, pero llegando a éste siempre que haga falta...", "De los resultados de la Conferencia de Berlín y del estado social de la cuestión obrera", en Problemas Contemporáneos, tomo III, Madrid, 1890, pp. 525 y ss., citado por GÓNZÁLEz CUEVAS, Pedro C., Historia de las Derechas españolas..., pp. 182 y ss.

30. MONTERO, F, "La polémica sobre el intervencionismo y la primera legislación obrera en España, 1890-1900. El debate académico", Revista de Trabajo, n. 59 y 60, p. 155, Madrid, 1980. Véase también, del mismo autor, "Conservadurismo y cuestión social", en TUSELL, J.; MONTERO, F. y Marín, J. M. ${ }^{\text {a }}$ (eds.), Las Derechas en la España Contemporánea.., pp. 59 y ss. 
El intervencionismo estatal se inscribirá, desaparecido el líder Antonio Cánovas, dentro de lo que se ha denominado el regeneracionismo conservador expresado por Francisco Silvela, Eduardo Dato ${ }^{31}$, y más tarde, por Antonio Maura.

Estas tres personalidades plantearon dos propuestas importantes dentro del campo conservador español: la necesidad de reformar el sistema político ahogado por el caciquismo y la corrupción mediante la reforma de la ley electoral y de la Administración Local, y la exigencia de una política social del Estado que limitara las posiciones revolucionarias del movimiento obrero de entonces.

Por lo que se refiere al primer punto, el sistema político español de la Restauración se basaba esencialmente, como es conocido, en el control caciquil del poder por camarillas de los dos partidos del turno, conservadores y liberales, en colusión de intereses con la nobleza terrateniente y la burguesía industrial, lo cual propiciaba una amplia corrupción política.

Sin embargo, dentro de los propios partidos beneficiarios de la situación había dirigentes políticos que perciben el cambio político y social que recorre la Europa de fin de siglo, una Europa que camina hacia la democratización política y social, hacia la expansión económica y política fuera de sus fronteras naturales, una Europa muy distinta de la del primer tercio del siglo XIX.

Además, la crisis desencadenada por la pérdida de las últimas colonias españolas en la guerra hispano-norteamericana de 1898 creará un ambiente favorable en la opinión pública española para las reformas políticas y sociales.

Estos dirigentes conservadores intentan realizar reformas que transformen el sistema político caciquil para evitar desde "arriba», la revolución "desde abajo», en frase conocida de Antonio Maura, y eso explica, además de la propia recepción del positivismo, el culto por la moral política y el énfasis en la necesidad de acercar la política al ciudadano. "Tanto Silvela como Maura, afirma el profesor Suárez Cortina, entendieron la regeneración como una dignificación de la política, más que como una verdadera modernización de la sociedad»32.

Efectivamente, la mayoría de los conservadores españoles no eran partidarios de una reforma democrática del sistema político y social, dado su pensamiento organicista tendían a reforzar la representatividad con el sufragio corporativo y una reordenación social nueva.

31. Sobre Eduardo Dato, ministro de la Gobernación con Francisco Silvela, y más tarde, a comienzos del siglo XX, él mismo Presidente de Gobierno, pueden leerse los trabajos de SECO SERRANo, Carlos, "Perfil político y humano de un estadista de la Restauración» (Discurso de recepción en la R. Academia de la Historia), Madrid, 1978; "Eduardo Dato y el catolicismo social", en SECO SERRANO, Carlos y otros, La cuestión social en la Iglesia Española Contemporánea, Zamora, 1981, pp. 75-93; MONTERO, F., "Conservadurismo y cuestión social", en Las Derechas en la España Contemporánea..., pp. 59-77. Sobre Antonio Maura y el maurismo: TUSELl, Javier y AVILÉS FARRÉ, Juan, La Derecha española contemporánea. Sus origenes. El maurisno, Madrid, 1986; GONZÁLEZ HERNÁNDEZ, M. Jesús, "Regeneracionismo, reformismo y democracia en Antonio Maura", en TUSELL, J.; MONTERO, F. y MARín, J. M. (eds.), Las Derechas en la España Contemporánea..., pp. 91-115.

32. SuÁrez Cortina, Manuel, La España Liberal (1868-1917), Madrid, 2006, pp. 154 y ss. 
Por otra parte, su estrecha vinculación con la ideología católica les impedía el avance y la comprensión de un mundo en trance de secularización, mientras el miedo al crecimiento del movimiento obrero les hacía mantener un sentido represivo del orden público.

Los intentos de reformas políticas sobre todo en la Administración Local y en el régimen electoral que llevaron a cabo los políticos citados anteriormente, el programa de descentralización administrativa que defendieron, y el intento de introducir, lo que se llamó la "representación de los intereses», es decir, el sufragio corporativo, fueron los elementos más destacados de este conjunto de reformadores conservadores a fines del siglo XIX y a comienzos del siglo XX.

Sobre el sufragio corporativo, como alternativa al sufragio universal, decía Francisco Silvela: "Con el sufragio universal, se gobierna, pero con el sufragio universal no se administra..., el ciudadano tiende a no valorar su derecho de voto y con facilidad lo vende por nada. En cambio, un mandato de un círculo, corporación o centro supone para el mandatario una mayor obligación, un seguro contra el fraude... utilizar para la construcción de los municipios, dentro del sistema electoral, el elemento colectivo, los gremios... ${ }^{33}$.

Así el sufragio corporativo constituiría un valladar frente a la falsificación del sufragio en una sociedad con una opinión pública demasiado débil para evitar la corrupción política; sin embargo, como acertadamente afirma Florentino Portero: «un liberal como Silvela recurría a sistemas no liberales con tal de avanzar, si bien peligrosamente, por el camino de una mayor representación... ${ }^{34}$.

En cuanto a las reformas sociales que pusieron en marcha como gobernantes fueron el resultado del trabajo previo desarrollado por intelectuales krausistas y en menor medida por católicos sociales, conservadores y liberales, con una presencia reducida, no hay que olvidarlo, de sus verdaderos protagonistas, los obreros y los patronos ${ }^{35}$.

Dicho trabajo se encauzó a través de la Comisión de Reformas Sociales, y el Instituto de Reformas Sociales creado en 1903, un organismo que dependía del Ministerio de la Gobernación, lo cual demuestra que en el fondo lo que subyacía en el reformismo social español era paternalismo, beneficencia y miedo a los grupos obreros ${ }^{36}$.

En la política de reformas sociales podemos señalar tres fases: la primera entre 1883 y 1903 , caracterizada por el análisis y debates sobre el hecho y las causas de la cuestión social, esturvo dirigida por la Comisión de Reformas Sociales; la segunda fase entre 1903 y 1917 se inicia con la creación del Instituto

33. SILVELA, F, «La organización municipal en las grandes ciudades" (conferencia de 30 de noviembre de 1895), citado por PORTERO, Florentino, «El regeneracionismo conservador: El ideario político de Francisco Silvela», en Tusell, J; MONTERo, F. y MARín, J. M. ${ }^{a}$ (eds.), Las Derechas en la España Contemporánea..., pp. 55.

34. PORTERO, F, «El regeneracionismo conservador: El ideario político de Francisco Silvela», en TUSELL, J; MONTERo, F. y MARÍn, J. M. a (eds.), Las Derechas en la España Contemporáned..., p. 55.

35. De la Calie VelasCo, $M^{a}$. Dolores, "Sobre los orígenes del Estado Social en España»..., pp. 138 y ss.

36. Véanse las obras de J. I. PALACIO MORENA sobre el tema, citadas anteriormente. 
de Reformas Sociales en 1903 cuya misión era preparar la legislación de trabajo, cuidar de su ejecución y favorecer la acción social y gubernativa, y sigue en 1908 con la creación del Instituto Nacional de Previsión que tenía una doble finalidad: difundir la necesidad de una previsión popular, en forma de pensiones de retiro y administrar la Mutualidad Voluntaria de Asociados subsidiada por el Estado $^{37}$. El tercer período comienza en 1917 y llega a 1926; se caracteriza por la necesidad de dar una respuesta a la creciente conflictividad social y a la propia crisis del sistema de la Restauración, fruto de ello fue la creación del Ministerio de Trabajo en 1920 por Eduardo Dato que agrupó al Instituto de Reformas Sociales y al de Previsión con el fin de tener un mayor control gubernamental de las acciones de ambos organismos.

El creciente enfrentamiento entre los intereses de obreros y patronos dentro del Instituto de Reformas Sociales inducen a pensar que esa sea la razón de la sustitución del Instituto de Reformas Sociales por un nuevo organismo, el Consejo de Trabajo en 1924 con representación patronal y obrera, pero mucho más controlable por el Gobierno. Esta etapa culmina con la construcción de un modelo corporativo basado en Comités Paritarios en 1926 en la Dictadura de Primo de Rivera.

Del intervensionismo estatal moderado, subsidiario, de épocas anteriores tal como habían defendido krausistas, conservadores y católicos, se ha pasado a un intervencionismo pleno donde el Estado y sus instituciones intervienen y deciden en el campo económico y social ${ }^{38}$.

Con las leyes sobre accidentes de trabajo (1900), Mujeres y Menores del mismo año y Descanso Dominical de 1904 se inaugura la legislación obrera en España, legislación preparada y elaborada desde 1903 por el Instituto de Reformas Sociales que se convierte en el instrumento de los liberales krausistas para encauzar las reformas sociales con el apoyo declarado de conservadores y católicos como Eduardo Dato.

En este mismo período destaca la aprobación de las leyes de Conciliación y Arbitraje industrial y de Tribunales Industriales de 1908, germen del futuro modelo corporativo de la Dictadura de Primo de Rivera (1923-1930).

Sin embargo, a pesar del crecimiento de la legislación social desde comienzos de siglo (sólo entre 1900 y 1910 se aprueban 531 disposiciones de carácter social y laboral), su virtualidad fue escasa por el propio rechazo y boicot de los

37. Sobre los Seguros Sociales en España contamos con Gómez MOLledA, M. ${ }^{a}$ Dolores (dir.), Los Seguros Sociales en España, Madrid, 1988, 3 vols.: Montero, F. y MARTínez Quinteiro, E., Orígenes y antecedentes de la Previsión Social, vol. I; CUESTA Bustrlo, Josefina, Hacia los Seguros Sociales obligatorios. La Crisis de la Restauración, vol. II; SAMANIEGo BONEU, Mercedes, La unificación de los Seguros Sociales a debate. La Segunda República, vol. III.

38. Véase mi artículo "Corporativismo y catolicismo social en la Dictadura de Primo de Rivera", en Tusell, J; Montero, F. y MARín, J. M. ${ }^{a}$ (eds.), Las Derechas en la España Contemporánea..., sobre todo las páginas 186 y ss.: "Lo esencial del entramado corporativo español es el papel omnipresente del Estado... tanto sobre las corporaciones, como sobre los sindicatos, ya que las corporaciones son organismos de derecho público por celegación del Estado, que a su vez mantiene funciones fiscalizadoras sobre los sindicatos...». 
empresarios españoles, e igualmente por la actitud de oposición de los sindicatos y el partido obrero, lo cual llevó a la inoperancia de la legislación social española como se muestra en las Memorias anuales de la Inspección de Trabajo que publicaba el Instituto de Reformas Sociales a partir de 1906, y donde se constataba "el grado de incumplimiento inicial de las leyes sobre el trabajo" ${ }^{39}$.

\section{c) Las alternativas del catolicismo español. Catolicismo político y Acción Social ${ }^{40}$}

La restauración de la monarquía borbónica en 1875, en la persona de Alfonso XII fue acogida con bastantes esperanzas por los católicos españoles tras el periodo revolucionario iniciado en septiembre de 1868 , caracterizado según la prensa católica "por la progresiva violación de todos los derechos de la Iglesia ${ }^{41}$. Sin embargo, el jefe de Gobierno, el conservador Antonio Cánovas necesitaba negociar la permanencia del nuevo régimen con los grupos liberales que habían participado en los inicios de la revolución de 1868.

Uno de los pilares del nuevo régimen político era no caer en errores de regímenes anteriores creando un sistema pragmático y flexible que permitiera gobernar a conservadores y liberales sobre la base de la tolerancia y los derechos individuales. Pero para los católicos, la unidad católica era irrenunciable y en consecuencia se opusieron a la libertad religiosa.

A pesar de las presiones de la jerarquía católica y el propio Vaticano, el Jefe de Gobierno conservador mantuvo en su proyecto de Constitución dentro de una declaración de confesionalidad del Estado una tolerancia restringida hacia las demás religiones.

La aprobación de este proyecto que se convirtió en la Constitución de 1876 agudizó la división de los católicos españoles, por un lado se situaron los católicos carlistas, que rechazaban la propia monarquía borbónica por liberal y añoraban la monarquía absoluta con unión del Altar y el Trono; este grupo contaba con un órgano de expresión de indudable influencia, "El Siglo Futuro» y el apoyo de una parte de la jerarquía eclesiástica; por otro lado, se situaban los católicos integristas, escindidos del carlismo en 1888, que ponían el acento no en la vuelta a la monarquía tradicional, sino en una concepción estrictamente confesional de la política y el poder, según la cual, todas las acciones debían

39. PALOMEQUE LópeZ, M. C., "La intervención normativa del Estado en la "cuestión social»", Ayer, n. ${ }^{\circ} 25$, Madrid, 1997, p. 126 y continúa diciendo «la falta de recursos presupuestarios, la actitud poco sensible a este propósito de las autoridades locales, y la propia desconfianza de los trabajadores destinatarios de las medidas normativas explican de suyo la insuficiente observancia de la legislación obrera.", Ibidem, p. 126.

40. Un estado de la cuestión sobre el catolicismo social español en MONTERO, F., «El catolicismo social en España. Balance historiográficon, en L'Histoire religieuse en France et en Espagne, Madrid, Casa de Velázquez, 2004, pp. 389-409. Una obra reciente, CuenCA ToRiBio, J. M., Catolicismo social y político en la España Contemporánea. 1870-2000, Madrid. 2003.

41. La España Católica, 2 de enero de 1875, citado por BENAVIDES, D., Democracia y cristianismo en la España de la Restauración, 1875-1931, Madrid, 1978, p. 13. 
estar subordinadas a la norma religiosa y a la institución eclesial ${ }^{42}$. Por último, había una minoría católica prestigiosa que acepta el régimen constitucional liberal y proponía crear un partido católico, la Unión Católica de Alejandro Pidal y Mon, similar al Zentrum alemán, como medio para defender mejor los derechos e intereses de la Iglesia, partido que constituyó un sonoro fracaso.

La división de los católicos respecto a la actitud a adoptar ante al régimen liberal fue notable a pesar de los llamamientos papales a la unidad, ello explica la organización de Congresos católicos a partir de los años 90 con la finalidad de ofrecer una plataforma unitaria a católicos de distintas tendencias. En estos Congresos participarán los tres sectores del catolicismo español, los integristas, encabezado por Ramón Nocedal ${ }^{43}$, el más numeroso, los unionistas de Alejandro Pidal, y los carlistas representados por el Marqués de Cerralbo.

En realidad, los Congresos católicos de fines del XIX representaron una posición defensiva y confusa respecto al liberalismo y a lo que se denominaba el mundo moderno y las nuevas ideologías obreras, esto se explicita en el reglamento del Congreso donde se propone "defender los intereses de la religión, los derechos de la Iglesia y del Pontificado, difundir la educación e instrucción cristianas, promover las obras de caridad y acordar los medios para la restauración moral de la sociedad» ${ }^{44}$.

El tratamiento de la problemática social en los Congresos católicos refleja la absoluta insuficiencia teórica de los análisis católicos dominados por la filosofía neotomista muy popular en los últimos años del siglo XIX.

La propaganda y acción social del catolicismo español se orientó a defender y pedir al Estado una legislación adecuada sobre sus intereses dominantes: la defensa y protección de la familia, el descanso dominical, la institución del gremio como instrumento de armonía social, la defensa de la propiedad sobre todo de la agraria y la organización corporativa.

El resultado se resume en propuestas caritativo-benéficas en línea con los intereses patronales. Y la exigencia de una intervención estatal subsidiaria para proteger a los más débiles.

42. «Su programa político-religioso intransigente casi teocrático, afirma Domingo Benavides, despertaba fácilmente las simpatías del clero. Era una especie de demagogia religiosa... que supuso un grave obstáculo para la participación de los católicos en la política de la nación... Y en esta labor obstruccionista contó siempre con el apoyo del hermano menor, el partido carlista...", en BENAVIDES, D., Democracia y Cristianismo en la España de la Restauración..., p. 143. Sobre el integrismo, puede consultarse CUENCA TORIBIO, José Manuel, "Integrismo», en Diccionario de Historia Eclesiástica, Madrid, 1972.

43. «El enfrentamiento entre la línea promovida por Roma (partidaria de aceptar como mal menor el régimen liberal vigente) con los integristas, afirma Feliciano Montero, obstaculizó en muchos momentos la marcha de las sesiones...", en Reformismo conservador y catolicismo social en La España de la Restauración, 1889-1902, Madrid, 1983, p.406.

44. SANZ DE DIEGO, Rafael M.a, "La Iglesia española y el reto de la industrialización", en GARCĺA VILLOSLADA, Ricardo, Historia de la Iglesia en España, t. V, La Iglesia en la España Contemporánea, Madrid, 1979, pp. 624 y ss. Puede leerse también CUENCA TORIBIO, José Manuel, Estudios sobre la Iglesia española del siglo XIX, Madrid, 1973, en especial, las pp. 177-205; URUGUEN, Begoña, Origenes y evolución de la Derecha española: El Neo-catolicismo, Madrid, 1986. 
El objetivo del catolicismo era más bien religioso que social (evangelización, reeducación cristiana de las clases populares para alejarlas de la propaganda socialista y anarquista y el ejercicio de la caridad por los patronos) ${ }^{45}$.

Como señala uno de sus más destacados especialistas, el profesor Montero, "el catolicismo social es en una gran medida una prolongación de la lucha contra el liberalismo. La verdadera clave de la superación del conflicto social está en la doctrina de la Iglesia. Reforma social y reconquista cristiana... son tareas coincidentes ${ }^{46}$.

Las coordenadas teóricas del catolicismo español del momento se movían en torno a tres parámetros esenciales: la consideración de la propiedad como derecho natural; la afirmación de la desigualdad humana y la nostalgia de los gremios medievales.

Sobre el derecho absoluto de propiedad de origen divino, atemperado por la caridad, ya se había pronunciado uno de los principales pensadores católicos del siglo XIX, Jaime Balmes en 1843, y este mismo análisis se mantiene en los años $80^{47}$.

En cuanto a la noción de desigualdad natural también es presentada por la Iglesia como una cuestión de derecho divino, "Es un hecho la desigualdad y hay que aceptarla como algo querido por Dios, desde y para siempre", se decía en sermones de la época ${ }^{48}$. La aceptación de esa existencia "natural» de ricos y pobres lleva a dos cuestiones importantes defendidas por los católicos españoles, cuya finalidad era limar el escándalo social de los ricos, en primer lugar, el rechazo del afán desmedido de las riquezas y la importancia de la caridad cristiana, punto de partida de la llamada función social de la propiedad, y en segundo lugar, la defensa teórica de la pobreza.

En este sentido, Antonio $M .{ }^{a}$ Claret, un sacerdote de enorme prestigio en la corte española señalaba en 1886 que «la vida del pobre es incomparablemente

45. El obispo de Madrid, Narciso Martínez Izquierdo, publicó un discurso en 1889 que refleja todo lo anterior: «Hoy, decía, existe una terrible escisión entre ricos y pobres; un abismo insondable los separa y ¿sabéis cuál es la causa?... Todo eso responde a los continuos esfuerzos del espíritu del mal que ha arrancado del corazón del pobre la paciencia... El único remedio para estos males es devolver a la caridad su carácter y filiación divinas y así es como nos la presenta la Iglesia, madre de los pobres y menesterosos", en MARTíneZ IZQuIERDO, N., Pastorales, circulares y discursos, Madrid, 1889, citado por PORTERo, J. Antonio, Púlpito e ldeología en la España del siglo XIX, Zaragoza, 1978 , p. 228.

46. MONTERO, F, "Los católicos sociales y los orígenes de la política social», Studia Historica-Historia Contemporánea, vol. II, n. ${ }^{\circ} 4$ (1984), p. 58.

47. Jaime Balmes decía en 1843: "Sean las que fueran las teorías con que las diferentes escuelas pretendan explicar el derecho de propiedad... lo cierto es que este derecho existe, que es inviolable, sagrado... fundado en la ley natural, sancionado por la divina...», en BALMES, J., Obras Completas, Madrid, 1949, vol. V, pp. 949 y ss. Es interesante leer al respecto, el artículo de MARTi, Casimir, "Datos sobre la sensibilidad social de la Iglesia durante los primeros 30 años del movimiento obrero en Españan, en Aproximación a la Historia Social de la Iglesia española contemporánea, Madrid, 1978, pp. 129 y ss.

48. Portero, J. A., Púlpito e ideología en la España del siglo XIX.., pp. 176 y ss. 
más tranquila que la del rico... la pobreza hace dulce la muerte, no porque cause desesperación, sino porque no crea lazos en la tierra... ${ }^{49}$.

En cuanto a la nostalgia de los Gremios medievales se mantenía como una constante en los planteamientos eclesiásticos sobre la llamada "cuestión social». Ya en 1872, el obispo de Salamanca, Dr Lluch, comentaba que «los gremios asociaban como en una misma familia al amo y al dependiente, al propietario y al proletario... la asociación era santificada por el principio y el sentimiento religiosos. El derecho del amo era tan sagrado para el jornalero como para el amo... nadie pensaba en trocar los papeles y el reparto de bienes... ${ }^{50}$.

El gran problema del catolicismo político y social español del siglo XIX y comienzos del siglo XX fue, por consiguiente, enfrentarse a las consecuencias sociales y económicas de la industrialización y a los nuevos desafíos derivados del laicismo, la democratización política, el incremento de la secularización, el auge del intervencionismo estatal, etc., a partir de unos presupuestos teóricos fosilizados que les impedían comprender las nuevas realidades sociales, políticas y culturales.

En consecuencia, muchos católicos con sensibilidad social se encontraron por un lado, coartados por las presiones conservadoras de la jerarquía eclesiástica, y por otro, sometidos a un pensamiento integrista que lastraba un mejor acercamiento a las nuevas realidades sociales y culturales.

\section{d) La acción social católica y el sindicalismo}

En el último tercio del siglo XIX se inicia en España la tarea de recuperar para el catolicismo al mundo obrero, cada vez más alejado de la Iglesia, por la extensión del socialismo y el anarquismo ${ }^{51}$.

La acción social de la Iglesia española se llevó a cabo mediante asociaciones mixtas de patronos y obreros que recordaban, y no por casualidad, los viejos gremios medievales arrumbados por el liberalismo y el capitalismo.

49. Claret, Antonio M. ${ }^{2}$, Prácticas Dominicales, Madrid, 1886, citado por PorTero, J. Antonio, Púlpito e ideología en la España contemporánea..., p. 219.

50. LlUCH GARRIGA, J., La Internacional, Salamanca, 1872, citado por JUTGLAR, Antoni, Ideología y clases en la España contemporánea, Madrid, 1969, pp. 126. Y continuaba diciendo «los verdaderos remedios del mal que aqueja a los obreros no son ni los jurados mixtos... ni la participación de los obreros en la propiedad de las empresas por medio de acciones, ni la disminución de horas de trabajo, ni el paulatino aumento del salario. La solución es educar al pueblo en la religión cristiana, haciéndolo justo, laborioso y sufrido...", p. 138.

51. Sobre la acción social y el sindicalismo católico pueden consultarse: LIORENS, M., «El P. Antonio Vicent (1837-1912): Notas sobre el desarrollo de la acción social católica en España", Estudios de Historia Moderna, n. 4 (1954), pp. 396-435; CUENCA ToRIBIO, José Manuel, Escritos del P. Vicent. Socialismo y anarquismo, Madrid, 1972; Del mismo autor, «EI P. Antonio Vicent y los orígenes del catolicismo social en España», en Estudios sobre la Iglesia española del XIX, Madrid, 1973, pp. 265-287; Sindicatos y partidos políticos católicos en España, fracaso ofrustración?, 1870-1977, Madrid, 2001; ANDRÉs Gallego, J., Pensamiento y acción social de la Iglesia en España, Madrid, 1984; GarCÍA NiETO, J. N., El sindicalismo cristiano en España, Bilbao, 1960; CASTLLo, J. José, El sindicalismo amarillo en España. Aportación al estudio del catolicismo social español, Madrid, 1977; CUESTA BUSTILLO, Josefina, Sindicalismo católico-agrario en España, Madrid, 1978. 
Estas asociaciones mixtas recibieron el nombre de Círculos Obreros y su principal impulsor, aunque no el único, fue el jesuita Antonio Vicent que se implicó en dicha tarea a partir de la publicación de la encíclica de León XIII Rerum Novarum en 1891.

En la formación de los Círculos Obreros tuvieron un papel importante las experiencias social-católicas francesas (marqués de La Tour du Pin, Albert de Mun, etc.), el pensamiento social alemán y austriaco (Monseñor Ketteler, barón de Volgesang), los Congreso católicos celebrados en Lieja y Malinas a comienzos de los 90, y por supuesto, la propia encíclica Rerum Novarum.

La cuestión fundamental para el catolicismo social español era determinar las causas del conflicto social, y en este sentido, siguiendo el magisterio de León XIII, el P. Vicent las redujo a tres: la apostasía religiosa de las naciones que han abandonado los principios católicos; el individualismo liberal, destructor de los antiguos gremios medievales, enemigo del origen divino del poder e impulsor del constitucionalismo y parlamentarismo; y finalmente, el socialismo, una ideología atea que rechaza la propiedad privada en favor de la colectiva y que está en contra del concepto tradicional de familia.

Para remediar la situación se crean los Círculos de Obreros integrados por dos tipos de socios, los numerarios, es decir, obreros en activo, y los socios protectores, propietarios, industriales, etc. El gobierno del Círculo estaba a cargo de una Junta formada por representantes de los socios numerarios y los socios protectores con un Consiliario nombrado por el obispo del lugar. En cuanto a sus fines, eran cuatro: el religioso, el instructivo, el económico y el recreativo ${ }^{52}$.

En realidad, el Círculo Obrero no era más que un centro de formación religiosa y profesional controlado por patronos y sacerdotes aunque la finalidad última era sustituir el sistema económico y político liberal por otro corporativo de inspiración cristiana.

El medio a utilizar sería el Gremio integrado voluntariamente por patronos y obreros del mismo oficio que desempeñaría una serie de funciones; en primer lugar, regularía las relaciones laborales entre empresarios y trabajadores a través de jurados mixtos que eliminarían el conflicto social; en segundo lugar, serviría de protección social para los más necesitados; en tercer lugar, reclamaría al Estado una legislación social adecuada; en cuarto lugar, sería el fundamento de un sistema político corporativo puesto que la generalización de los Gremios y el abandono del individualismo permitiría unas Asambleas legislativas corporativas.

La extensión de los Círculos Obreros y los debates sobre la acción social católica llevados a cabo en los distintos Congresos Católicos de fines del siglo XIX plantearon la necesidad de una unión nacional de círculos, que se llevó a cabo en 1893 en Valencia. En esta ciudad y al hilo de las orientaciones realizadas por la encíclica leonina se funda el Consejo Nacional de las Corporaciones Católicas. La estructura creada parte de las diócesis y sus consejos diocesanos

52. Benavides Gómez, Domingo, Democracia y Cristianismo en la España de la Restauración, 1875 $1931 \ldots$, p. 215. 
que presididos por el obispo del lugar, junto con un presidente elegido por 3 años, ejercerían la labor de vigilar, supervisar y coordinar todas las asociaciones obreras. En la cúpula se hallaba el Consejo Nacional integrado por todos los presidentes de los consejos diocesanos.

El primer Consejo Nacional elegido en dicha reunión estuvo formado, entre otros integrantes, por el arzobispo de Valencia y el marqués de Comillas como Presidentes honorarios, junto al obispo de Segorbe, y como Presidente efectivo el P. Antonio Vicent.

Tres años después, en 1896, se elige un nuevo Consejo Nacional en una asamblea celebrada en la capital de España que estaba compuesto entre otros por el Nuncio de Su Santidad y los arzobispos de Valencia y Madrid, junto con el marqués de Comillas como Presidentes honorarios, y como presidente efectivo el duque de Sotomayor asesorado por el consiliario general, P. Vicent.

Como puede comprobarse por los nombres de los dirigentes del Consejo Nacional de Corporaciones católico-obreras, éste resultó ser un organismo controlado por la aristocracia y la alta burguesía española, junto al episcopado, donde los obreros tutelados eran considerados menores de edad.

En 1901, un católico social, Maximiliano Arboleya, canónigo de la catedral de Oviedo, que defenderá el sindicalismo cristiano puro, afirmaba lo siguiente sobre las corporaciones católico-obreras: "Diráase que esos centros no tiene más objeto que ilustrar al obrero en cuestiones religiosas, darle una instrucción más completa en su arte, hacerle más sufrido y resignado con las injusticias de que es objeto...." ${ }^{53}$.

Según los datos ofrecidos por el propio Consejo Nacional de Corporaciones Católico-Obreras de España, en 1900 estaban integradas en él 264 agrupaciones desde Círculos a Gremios, o Cajas de Ahorros, que representaban a más de 76.000 asociados $^{54}$.

A pesar de estas cifras, el crecimiento de las organizaciones socialistas en España a comienzos del siglo XX y la constitución más adelante del sindicato anarquista CNT, revelaron la insuficiencia de la alternativa católica, lo cual llevó a su propio creador, el P. Vicent, a subrayar en 1904 el fracaso de los Círculos con las siguientes palabras: "En la práctica, ¿qué hemos obtenido en tantos círculos católicos...? En realidad, ha sido muy poca cosa... los patronos han reclamado siempre la absoluta libertad de contratación, y los obreros, han rechazado unirse con los patronos para conseguir el gremio cristiano.... ${ }^{55}$.

53. ARBOLEYA MARTINAEZ, Maximiliano, Liberales, socialistas y católicos ante la cuestión social, Valladolid, 1901, pp. 61-63, citado por BENAVIDES GOMEZ, Domingo, Democracia y Cristianismo en la España de la Restauración, $1875-1931 \ldots$, p. 224 y continuaba diciendo: «A los obreros de nuestros círculos se les habla de religión, de moralidad, de resignación, de sus obligaciones... pero casi nunca se les habla de sus legítimos derechos...».

54. Datos recogidos por BENAVIDES, Domingo, Democracia y cristianismo en la España de la Restauración, 1875-1931..., p. 222.

55. VICENTE, A., en Boletín del Consejo Nacional de las Corporaciones Católico-Obreras, Madrid, 1904, p. 14, citado por BENAVIDES, Domingo, Democracia y Cristianismo en la España de la Restauración, 1875-1934..., pp. 225 y ss. 


\section{EL PROYECTO CORPORATIVO DE LA DICTADURA DE PRIMO DE RIVERA ${ }^{56}$}

La dictadura de Miguel Primo de Rivera no fue un mero interregno entre la Restauración y la Segunda República, sino un período donde se debatieron, elaboraron y experimentaron todo un conjunto de proyectos sociales y políticos, tanto de raíz autóctona, como europea, que influirán decisivamente en los años posteriores, época republicana y franquista ${ }^{57}$.

Si la dictadura de Primo de Rivera es la consecuencia del colapso del sistema de la Restauración, conviene recordar que éste se produce en el marco de una crisis generalizada del modelo político, social y económico liberal en toda Europa tras la Primera Guerra Mundial.

Esto explicaría las discusiones sobre nuevos modelos sociales alternativos al liberalismo que se extienden por España y toda Europa dentro de lo que Maier definió como un intento de refundar la Europa burguesa, dando «nueva cohesión al orden social... al mismo tiempo que los europeos buscaban la estabilidad... ellos mismos creaban nuevos ordenamientos institucionales... la evolución hacia el corporativismo entrañó un declive del Parlamento.... ${ }^{58}$.

Bien es verdad que aunque Primo de Rivera pretendiera crear a partir de 1926, fascinado por el ejemplo italiano, no sólo un modelo de corporativismo social, sino un modelo de corporativismo político cuyo reflejo será el proyecto constitucional de $1929^{59}$, lo cierto es que no había las condiciones sociales y políticas para la realización de un proyecto político autoritario cercano al fascismo italiano en aquellos años.

No obstante, durante el período dictatorial se forjarán los argumentos doctrinales que servirán de base a la derecha radical en el período de la Segunda República: exaltación del mito del jefe, estructuración jerárquica de la Unión Patriótica, concebida como un movimiento político integrador de tipo nacional, al margen de los partidos políticos tradicionales, teorías organicistas políticas y sociales, y sobre todo un concepto de Nación-patria de carácter esencialista

56. Puede verse mi ensayo "Regeneracionismo y Corporativismo en la Dictadura de Primo de Riveran, en TUSELl, J.; MONTERo, F. y MArún, J. M. ${ }^{2}$ (eds.), Las Derechas en la España Contemporánea..., pp. 177-196.

57. Sobre la naturaleza de la dictadura de Primo de Rivera escribí uno de los primeros estados sobre la cuestión titulado «La Dictadura de Primo de Rivera: 60 años despuésn, Studia Historica-Historia Contemporánea, vol. I, n. ${ }^{\circ} 4$ (1983), pp. 223-227.

58. MAIER, S. Charles, La refundación de la Europa burguesa, Madrid, 1989, pp. 23 y ss.

59. En su manifiesto al país de 5 de septiembre de 1926 señalaba que «Fracasado el Sistema parlamentario en su forma actual... el Gobierno y la Unión Patriótica tienen la concepción de un Estado de nueva estructura... célula principal de la nación ha de ser el municipio, y de él, la familia, con sus rancias virtudes y su moderno concepto ciudadano. Núcleo, la provincia, y vértebra principal que dirija todo el sistema, el Estado...", PRIMO DE RIVERA, Miguel, El pensamiento de Primo de Rivera, Madrid, 1929, pp. 34 y ss. Sobre las relaciones de las dos dictaduras mediterráneas puede leerse TUSELI, J. y SAZ, I. "Mussolini y Primo de Rivera, las relaciones políticas y diplomáticas de dos dictaduras mediterráneas", Boletin de la Real Academia de la Historia, t. CLXXIX, 1982, p. 426. 
dotada de una dirección moral, junto con un nuevo tipo de Estado coordinador y director de la economía y la vida social.

En definitiva, la dictadura de Primo de Rivera supuso un experimento político nuevo, ante los problemas derivados del colapso del sistema liberal de la Restauración que aun incorporando determinados elementos del pensamiento tradicionalista y católico español (antiparlamentarismo, defensa de la familia y de la religión, rechazo de la lucha de clases y de las ideologías obreras, consideradas disolventes de la sociedad), introduce conceptos modernizantes como el papel del Estado autoritario, coordinador y regulador de las actividades económicas y sociales ${ }^{60}$.

La dictadura destruyó el sistema político liberal, impidiendo la estabilización política y social en un sentido democrático e inició una propuesta corporativa y autoritaria que superase el viejo modelo liberal oligárquico, pero, como dijo su ministro de Trabajo, Aunós: "En aquella España de 1926 una estructura corporativa totalitaria hubieses chocado contra los prejuicios liberaloides de la burguesía... y de las clases obreras desorganizadas y sometidas al vasallaje de ideologías antinacionales.... ${ }^{51}$.

El corporativismo primorriverista fue obra de Eduardo Aunós, subsecretario y más tarde, ministro de Trabajo, un hombre miembro de una familia conservadora acomodada de Lérida, de formación krausista, que había sido secretario de Cambó. Aunós recibe la doctrina organicista a través de una triple fuente, el krausismo, el nacionalismo catalán y el catolicismo social francés y español, además su observación sobre los mecanismos paritarios para la resolución de los conflictos sociales, experimentados en Cataluña, tras su puesta en marcha por el Instituto de Reformas Sociales le prepara para encarar uno de los grandes problemas de las élites gobernantes: la resolución del conflicto social mediante fórmulas de armonía social que reduzcan los efectos del problema social y desactiven al movimiento obrero organizado.

Por otra parte, Aunós fue un gran estudioso de todas las fórmulas autoritarias y totalitarias que se extendían en la Europa de entreguerras, sus relaciones personales con el gran teórico del corporativismo italiano Bottai lo prueban, igual que sus lecturas, e influencias de la Carta de Carnaro, obra del poeta

60. Esta tesis la hemos sostenido desde 1982 en la tesis doctoral, y en diversos artículos, entre ellos, «Bases ideológicas de la Política Social de la Dictadura», Studia Zamorensia Historica, vol. VII, 1986, pp. 513-522; y en nuestro ensayo "Regeneracionismo y Corporativismo en la Dictadura de Primo de Rivera», en Tusell, J.; MONTERo, F. y MARín, J. M. ${ }^{a}$ (eds.), Las Derechas en la España Contemporánea..., pp. 177-196. En esta misma perspectiva, GIL PECHARRomán, Julio, Conservadores subversivos. La derecha autoritaria alfonsina, 1913-1936, Madrid, 1994: "Su modelo de Estado corporativo... le apartaba de los esquemas del catolicismo social y del tradicionalismo español representado entonces por figuras como Vázquez de Mella y Gafo, para introducir un elemento de modemidad totalitaria, que afectaría luego a corrientes de la extrema derecha como el falangismo y el neotradicionalismo alfonsino...p, p. 51. En la misma línea, el libro reciente de GONZÁlEz CALlEJA, Eduardo, La España de Primo de Rivera. La modernización autoritaria, 19231930, Madrid, 2005.

61. AUNÓs, Eduardo, La reforma corporativa del Estado, Madrid, 1935, pp. 136 y ss. 
prefascista D'Annunzzio, los escritos de Alfredo Rocco, o de los escritores alemanes como O. Spann u Otto Gierke, inspiradores del nuevo Derecho alemán, tras la asunción del poder por Hitler.

El nacionalismo europeo de los años 20 recoge las doctrinas románticas que identifican Estado, Sociedad y Nación, junto al organicismo como fórmula de estructuración social. Pero, al mismo tiempo asume el pensamiento burgués sobre la necesidad de las élites y la jerarquía social, junto al sindicalismo revolucionario y las doctrinas racistas.

Este conjunto heterogéneo de planteamientos básicamente antiliberales y antiparlamentarios se presenta como una doctrina modernizadora del orden social y político frente a un liberalismo en retroceso, incapaz de adaptarse a los enormes cambios que siguieron a la primera conflagración mundial.

Todo lo cual nos revela en Aunós a un hombre en posiciones diferentes al tradicionalismo y catolicismo social español, y al contrario, inserto dentro de la gran corriente autoritaria, antiparlamentaria y antiliberal que se extiende por Europa, tras la Primera Guerra Mundial. Su propia trayectoria durante la Segunda República y el primer franquismo donde milita en la derecha radical nos lo confirma, y su modelo corporativo social sirvió de base al sindicalismo franquista, en mayor medida que el proyecto sindical de la Falange.

El experimento corporativo primorriverista se inicia con el Decreto-Ley de Organización Corporativa Nacional de 26 de noviembre de 1926 y culmina con el Decreto-Ley sobre Organización Corporativa de la Agricultura de 12 de mayo de 1928. El esquema doctrinal del corporativismo primorriverista parte de la necesidad de solucionar la llamada "cuestión social» mediante la intervención del Estado en los problemas sociales, encuadrando la clase obrera y patronal en estructuras - no sindicales-de conciliación obligatoria.

Se ha especulado mucho sobre la influencia católico-social en la estructura corporativa española a partir de las propias declaraciones de Aunós sobre las aportaciones del catolicismo social francés y español a su proyecto, e incluso sobre las indisimuladas simpatías de la élite católica social española desde su órgano de expresión, El Debate.

Sin embargo, un estudio completo tanto de los textos corporativos escritos por los hermanos Aunós, sus relaciones personales, así como la trayectoria posterior en la República y el franquismo, como ya hemos indicado, no nos permite afirmar el carácter católico-social del corporativismo primorriverista.

Como hemos defendido en otros ensayos ${ }^{62}$, el proyecto corporativo de la dictadura obedece a otros supuestos ideológicos; si para el catolicismo social del siglo XX el principio básico era la subsidiaridad del Estado, el modelo primorriverista se basa, al contrario, en la preeminencia del Estado en la vida social y económica. "Corresponde al Estado, decía Aunós, una función ética en la que

62. «Corporativismo y Catolicismo Social en la Dictadura de Primo de Rivera», Studia HistoricaHistoria Contemporânea, vol. II, n. 4 (1984), pp. 123-148. 
el moderno Estado Social tiende a superar los supuestos del Estado Liberal y abstencionista.... ${ }^{63}$.

El modelo de Estado Corporativo de Aunós partía de la idea de la estructuración del país como una organización de "productores" por parte de un Estado fuerte que armoniza intereses y controla todas las actividades humanas «desde las más espirituales hasta las más predominantemente manuales" ${ }^{64}$.

Dicho Estado se caracterizaría por el sentido de la disciplina, impuesta por un Gobierno fuerte; el sentido de la jerarquía, entendida como estructuración social de la ciudadanía, y la ordenación funcional, es decir, la sujeción de todos los organismos al Estado que coordinaría y planificaría la vida económica y social, atendiendo al predominio de los intereses colectivos sobre los individuales ${ }^{65}$.

Todo lo cual refleja un tipo de Estado intervencionista y organicista donde "nada de lo que tenga trascendencia en la vida social y afecte al interés colectivo quede al margen (del Estado) ${ }^{66}$.

En la esencia misma del experimento corporativo dictatorial se encuentra una nueva teoría del Estado "que no quiere darlo todo al individuo, ni reconocerlo como único factor capaz de decidir sobre sus destinos... pretende que el individuo actúe centrando su actividad dentro de los cuerpos especializados y representativos de su categoría de trabajo, y que estos cuerpos vayan a confluir en la organización y ordenación del Estado.... ${ }^{67}$.

El armazón del corporativismo social de Aunós partía del Comité Paritario, organismo de derecho público con funciones delegadas del Estado estructurado como una asociación mixta de patronos y obreros, con un Presidente y un Secretario designados por el Ministerio de Trabajo. Sin embargo, no había dependencia entre las instituciones paritarias y las agrupaciones sindicales y patronales. Éstas se limitaban por ley a elegir a sus miembros en dichos Comités que los investían, después, como funcionarios públicos.

Entre las razones de esta peculiar estructura se encontraba el carácter marginal del sindicalismo en el modelo corporativo de Aunós, como éste subrayó repetidamente, y la inexistencia de unos sindicatos del régimen. Por eso se insistió en la superación del sindicalismo, "residuo del liberalismo" en el marco del nuevo Estado Corporativo, en consecuencia, sería éste quien asumiría la defensa de los obreros, armonizando sus intereses con el interés general del Estado.

63. Aunós, E., Estudios de Derecho Corporativo, Madrid, 1930, pp. 48 y ss. y continuaba diciendo «Este contenido realista de la voluntad ética del Estado, que se traduce en el sistema y orden de las tareas objetivas que constituyen en su propia base las corporaciones autónomas del trabajo, ha de ser integrado... con la idea de autoridad.....

64. Aunós, Eduardo, El Estado Corporativo, Madrid, 1929, pp. 14 y ss.

65. Eduardo Aunós decía al respecto: «Nuestra época es esencialmente orgánica e intervencionista. La aspiración de los Estados es que nada de lo que tenga trascendencia en la vida social ya afecte al interés colectivo quede al margen...", en Estudios de Derecho Corporativo, Madrid, 1930, p. 49.

66. Aunós, E., Estudios de Derecho Corporativo..., pp. 47 y ss.

67. Aunós, E., Las Corporaciones de Trabajo en el Estado Moderno, Madrid, 1928, p. 143. 
El Comité Paritario disponía de funciones legislativas en el ámbito laboral sobre todo la fijación de los pactos colectivos de trabajo que regulaban las relaciones de trabajo en un determinado sector industrial. Dichos pactos colectivos se diferenciaban de los acuerdos entre patronos y sindicatos por su generalidad ya que afectaban a todos los obreros y a todos los patronos del sector, estuvieran o no representados en el Comité Paritario, y por su obligatoriedad, dado que era el Estado el que concedía una eficacia generalizada a los acuerdos celebrados. Además de las funciones legislativas, el Comité Paritario disponía de facultades jurisdiccionales en materia de despido, creando una dualidad jurisdiccional con los Tribunales Industriales creados en 1908.

Los pactos colectivos de trabajo disponían de todas las características que la ley italiana de 3 de abril de 1926 especificaba para ellos. La diferencia más notable, en el caso español, se hallaba en que en España los pactos colectivos se realizaban en el marco de un organización suprasindical, tutelada y controlada por el Estado, mientras que en Italia se llevaban a cabo mediante las asociaciones sindicales fascistas de obreros y patronos.

El reparto de competencias judiciales entre los distintos escalones del sistema corporativo y la escasa formación jurídica de sus miembros llevaron a plantear al Ministerio de Trabajo la creación de auténticos Tribunales de Trabajo, en el marco del sistema judicial tradicional, similares a los que había creado el fascismo italiano, pero la caída de la dictadura imposibilitó su constitución ${ }^{68}$.

Por último, el Comité Paritario tenía competencias sobre la formación profesional y sobre la elaboración de censos profesionales. Por encima del Comité Paritario, en una estructura jerarquizada que culminaba en el propio Ministerio de Trabajo, se hallaban las Comisiones Mixtas, formadas por agrupaciones voluntarias de comités paritarios de industrias conexas. Sus funciones consistían en juzgar las infracciones a los acuerdos de los comités paritarios o los despidos.

Los Comités Paritarios del mismo oficio elegían el Consejo de Corporación que determinaba las condiciones generales de reglamentación del trabajo; resolvía las reclamaciones de los Comités paritarios, sancionaba los recursos presentados contra los acuerdos de los Comités Paritarios y finalmente asesoraba al Gobierno en cuestiones laborales. Había 27 Consejos de Corporación, distribuidos entre 10 Consejos del sector servicios, 15 del sector industrial y 2 para el sector de la minería. El esquema corporativo se completaba por arriba con la Comisión delegada de Consejos de Corporación, organismo asesor del Ministerio de Trabajo para cuestiones laborales.

Como puede comprobarse, el sistema corporativo no sólo era piramidal, con una destacadísima presencia gubernamental, sino que presuponía una nueva concepción según la cual el Estado descentralizaba sus funciones en el organigrama corporativo, de ahí a la expresión «unidad de poder y descentralización de funciones» del franquismo sólo hay un paso.

68. AUNós, Eduardo, La reforma Corporativa del Estado..., p. 136. 
La Organización Corporativa Nacional de 1926 que afectaba, esencialmente, al mundo del trabajo en la industria, se completó en 1927 con la constitución de la Organización Corporativa del Trabajo a Domicilio (20 de octubre de 1927) y la Corporación de la Vivienda (17 de octubre de 1927); la primera regulaba un sector, entonces muy importante de la producción (confección de ropa, calzado, guantes, géneros de punto, juguetería, joyería y platería, artesanía, etc.) y se estructuraba en Comités Paritarios de patronos y obreros con el objetivo de fijar un salario mínimo general que acercara el nivel salarial de sus trabajadores al de los obreros del sector industrial.

Para garantizar la aplicación de sus acuerdos se creaban Comisiones Mixtas Inspectoras, tuteladas por el servicio de Inspección de Trabajo y asesoradas por el Patronato del Trabajo a Domicilio formado por 4 vocales, representantes de las partes presentes en el Consejo de Trabajo (patronal, obreros, entidades culturales y Gobierno), más 2 vocales designados por las Asociaciones Protectoras del Trabajo a Domicilio.

Por lo que se refiere a la Corporación de la Vivienda estaba formada de forma igualmente paritaria, por las Cámaras de la Propiedad Urbana y las Asociaciones de Inquilinos y se ocupaba de la resolución de todas las cuestiones que afectaban a propietarios e inquilinos (contratos, uso de las viviendas), además de la creación de mecanismos de cooperación entre los dos sectores como el seguro de pago de alquileres, los abastecimientos o la prevención de los conflictos entre propietarios y arrendatarios. En la cúspide de esta organización corporativa de la vivienda se hallaba el Consejo de la Corporación de la Vivienda, dependiendo directamente de la Dirección General de Corporaciones del Ministerio de Trabajo.

Por último, el 12 de mayo de 1928 se aprobó el Decreto Ley de Organización Corporativa de la Agricultura que pretendía dar cabida, según decía el preámbulo del decreto, a una institución mixta que agrupara a todos los intereses agrarios, procurando armonizar el criterio de unidad con el de la variedad típica de la organización social de la tierra ${ }^{69}$.

La tardía creación de la Organización Corporativa de la Agricultura se debió, según un especialista agrario de la época, a la complejidad de crear un sistema corporativo en el campo dada la diversidad de situaciones ${ }^{70}$.

La Organización Corporativa de la Agricultura se estructuraba en tres grandes Corporaciones, a su vez formadas por Comités Paritarios como en la industria: la Corporación de Trabajo Rural, que agrupaba a patronos y obreros agrícolas; la Corporación de Propiedad Rústica, formada por propietarios y arrendatarios, colonos y aparceros; y finalmente, la Corporación de la Industria Agrícola, integrada por productores de materias primas y los representantes

69. Gaceta de Madrid, de 22 de mayo de 1928.

70. T.J.L., "Breves ideas sobre la organización agraria en España", Revista de Politica Social, n. ${ }^{\circ} 3$ (1928), p. 137: "salvo en Andalucía y Extremadura, tierras de latifundios donde se determinan con trazos vigorosos los grupos patronales y obreros, el cultivo del agro se diversifica en muititud de situaciones intermedias...». 
de las industrias agrarias; de esta Corporación estaban excluidos los obreros de las propias industrias, sujetos al Decreto Ley de Organización Corporativa Nacional de 1926.

La puesta en marcha de la Organización Corporativa de la Agricultura tropezó con dos problemas importantes, en primer lugar, la definición de sindicato agrario y asociación patronal, algo necesario para el funcionamiento de los comités paritarios y la elección de los vocales que los integraban; y en segundo lugar, el procedimiento electoral, proporcional o mayoritario, que serviría de base para elegir a los miembros de los comités.

En el primer caso, la definición de sindicato o patronal agrarios partía de una realidad en la que los sindicatos agrícolas de la época eran mixtos y por lo tanto tenían, según el decreto, que convertirse en organizaciones puras de empresarios o de obreros agrícolas. Por ello, el propio ministro de Trabajo planteó la puesta en marcha del Decreto en dos fases, una provisional, con agrupaciones paritarias de gran alcance territorial, y más tarde, se irían formando poco a poco los diferentes comités paritarios locales, interlocales y provinciales ${ }^{71}$. En cuanto al modelo de elección de los vocales en el campo se diseñó un sistema proporcional para favorecer los intereses del sindicato socialista UGT, aliado del ministro de Trabajo, frente a la gran patronal católica, la CONCA, que defendió el mayoritario, como en la industria. De esa manera, la UGT tendrá la oportunidad de crecer en el campo españo ${ }^{72}$, mientras que el sistema mayoritario de la industria les permitía marginar a los sindicatos católicos y los libres.

Sobre la colaboración socialista con la dictadura ${ }^{73}$, y en especial, su participación en el sistema corporativo conviene señalar, lo siguiente; en primer lugar, el objetivo básico del sindicato UGT, desde sus inicios, consistió en el mantenimiento de su organización a toda costa moderando, si era preciso, sus posiciones reivindicativas ${ }^{74}$; en segundo lugar, la búsqueda de la hegemonía sindical frente a los anarquistas y los católicos, para ello utilizarán todos los cauces que les ofrecía la dictadura, desde el Estatuto municipal de Calvo Sotelo, hasta la Organización Corporativa o la presencia en el Consejo de Trabajo y el Consejo de Estado, sin olvidar que existía dentro del sindicato y el propio PSOE una corriente corporativista que hundía sus raíces en el krausismo español,

71. AunÓs, E., Estudios de Derecho Corporativo..., p. 155.

72. "Las campañas de propaganda iniciadas en 1928 por zonas rurales... fueron la base sobre la que se procedería a la definitiva constitución de la Federación Nacional de Trabajadores de la Tierra... Para estos nuevos afiliados... ser socialista... consistía en implantar los comités paritarios...", en JULIÁ, Santos, Los socialistas en la política española..., pp. 136 y ss.

73. Puede leerse el libro de ANDRÉS GALIEGO, J., El Socialismo durante la Dictadura, Madrid, 1977, en especial las pp. 86-88. Más reciente la obra de JuLIÁ, Santos, Los Socialistas en la políica española, Madrid, 1997.

74. MORAL SANDOVAL, Enrique: «El primer objetivo que se proponen las organizaciones socialistas... consiste en proseguir se reestructuración general a todos los niveles, así como el mantenimiento de la organización ante el peligro real que representaba la Dictadura...", en "El socialismo y la Dictadura de Primo de Rivera", en JULIÁ, Santos (ed.), El Socialismo en España, Madrid, 1986, pp. 195 y ss. 
pero también en el laborismo británico, la socialdemocracia austriaca, e incluso dentro de la propia Organización Internacional del Trabajo ${ }^{75}$. En tercer lugar, la propia división del PSOE entre los que defendían que el sindicato era la correa de transmisión del partido, vanguardia del proletariado, de acuerdo con la especialización de tareas (Indalecio Prieto y Fernando de los Ríos, entre otros), y los que, en cambio, subrayaban la necesidad de una autonomía real del sindicato frente al partido e incluso la acción política del sindicato, como el propio sindicalismo británico (Largo Caballero y Luis Araquistain, entre otros) ${ }^{76}$.

En definitiva, la estructura corporativa de la dictadura significó la puesta en marcha de un moderno Derecho del Trabajo, y el fin de las relaciones laborales individuales llevadas a cabo por trabajadores y empresarios, su influencia sobre los proyectos laborales republicanos, los Jurados Mixtos implantados por Largo Caballero y el propio sindicalismo vertical franquista es innegable.

\section{NEOCORPORATIVISMO}

La historia del nacimiento y construcción de una teoría neocorporativa a partir de los años 60 del siglo XX, tiene que ver con una doble constatación: la extensión de regímenes políticos de carácter socialdemócrata en la mayor parte de los países europeos, y la consideración de que el viejo sistema de representación pluralista liberal pasaba por una grave crisis.

El sistema pluralista, formulado en Estados Unidos en la década de los 50 y 60 se basaba en la existencia de un mercado político donde cada grupo reclutaba a sus miembros y proponía medios de acción que suscitaban el sostén de la población.

De la interacción entre los grupos entre sí, con el Estado como árbitro, surgirían políticas tendentes a desarrollar el denominado "mínimo social óptimo" "77.

75. Véase las opiniones de Largo Caballero en diferentes artículos publicados en El Socialista: «La organización corporativa paritaria y la organización obrera (4, 8 al 15 de marzo de 1927); "La organización corporativa, decía, es un aspecto de la democracia económica que permitirá librar de grandes trastornos a la economía nacional... La función de los comités paritarios podrá satisfacer los anhelos de pacificación social o de humanización de las relaciones entre capital y trabajo...» o las palabras favorables del socialista Albert Thomas, Presidente de la Organización Internacional de Trabajo a la obra de Aunós prologando libros de éste sobre la organización corporativa española.

76. PÉREZ LEDESMA, M., "Partido y Sindicato: Unas relaciones no siempre fáciles», en JULIÁ, Santos (ed.), El Socialismo en España.., pp. 213 y ss.

77. Sobre estos planteamientos, existe una vasta bibliografía, centrada sobre todo en el campo sociológico, con escasas aportaciones de historiadores, entre otros, puede consultarse: SCHMITTER, Ph. C., "Neocorporativismo y Estado", REISS, n. 31 (1985), pp. 40-63; BERGER, S. (ed.), La organización de los grupos de intereses en Europa Occidental, Madrid, 1988; LEMBRUCH, G., "Democracia consociacional, lucha de clases y nuevo corporativismo", Papeles de Economía Española, n. ${ }^{\circ} 22$ (1985); Giner, S. y Pérez Yruela, M., La sociedad corporativa, Madrid, 1979; Giner, S. y PÉrez Yruela, M. (eds.), El Corporatismo en España, Madrid, 1988; Giner, S. y SaRASA, S. (ed.), Buen Gobiemo y Politica Social, Madrid, 1997; ESPINA, A., "Armonización de intereses versus lucha de clases», en SANZ MENÉNDEZ, L. (ed), Representación de intereses y políticas públicas: ¿Corporatismo o Pluralismo?», Zona Abierta, n. ${ }^{\circ} 67 / 68$ (1994); NiARTínEZ ALIER, J., "Viejas ideologías y nuevas realidades corporativistas", REISS, n. 31 (1985), pp. 119-142; PICÓ, J., Teorías sobre el 
Estas tesis han sido atacadas por otros sociólogos para quienes el proceso de formación de grupos de intereses, reduce el carácter representativo del sistema, al favorecer la estructuración y jerarquización social.

De hecho, la denominada teoría pluralista, germen de las posiciones neocorporativas, pone el acento en la intervención de los grupos sociales de intereses, sobre la intervención directa de los ciudadanos que reclamaba el liberalismo clásico.

El pensamiento neocorporatista plantea la necesidad de una integración progresiva de los distintos grupos sociales de intereses en el proceso de elaboración y puesta en práctica de las políticas públicas. Dicha integración se lograría mediante la institucionalización de los grupos de intereses y la práctica sistemática de políticas de negociación y compromiso. Esto implicaría el reforzamiento de los sindicatos y organizaciones empresariales como agentes de desarrollo de políticas públicas, compartiendo las responsabilidades con el Gobierno.

En realidad, las propuestas neocorporatistas representan, por una parte, la continuidad de la tradición corporativa social del siglo XIX, alejada, obviamente, de su carácter político autoritario, y la búsqueda de nuevas fórmulas políticas y sociales que resuelvan los problemas del liberalismo político clásico sobre la base de un modelo de democracia de consenso, alejado del modelo representativo y partidario tradicional.

Estado del Bienestar, Madrid, 1987; ZARAGOZA, A. y VARELA, J. «Pactos sociales y corporatismo en Españan, en ZARAGOZA, A. (ed.), Pactos sociales, sindicatos y patronal en España, Madrid, 1988, pp. 43-75; WiLSON, E. L., "Neocorporativismo y auge de los movimientos sociales", en DALTON, R. J. y KUECHLER, M. (eds.), Los Nuevos Movimientos Sociales, Valencia, 1992, pp. 101-123. 